\title{
Investing in Tough Times \\ What investors' behavior across the business cycle tells about the mutual fund market
}

\author{
Marco Navone ${ }^{1}$ \\ University of Technology \\ Sydney \\ This Draft: November, 2012 \\ Preliminary. Please do not quote without the author's consent
}

\begin{abstract}
In academic literature mutual fund investment has been traditionally studied from the perspective of an optimal portfolio allocation problem. An increasing body of empirical and experimental evidence has suggested that the investors' behavior share remarkable similarities with the behavior of buyers in consumer goods markets. In this study develop and test a number of hypotheses based on empirical evidence in marketing literature. Using data on US mutual funds from 1991 to 2011 I show that investors price awareness (sensitivity of investment flows to expense ratios) increases as the macroeconomic environment worsens. I also show that this effect is due to expectations of future economic hardship rather than to the current situation. These results are robust to alternative explanations based on time-varying risk aversion, informativeness of past performances and competition from low-cost passive funds. Finally, using a new dataset of advertising expenditures I show that advertising becomes more effective in tough times, also due to the fact that, contrary to common beliefs, high advertising budgets are paid through increased volumes rather than higher expense ratios.
\end{abstract}

Keywords: Business Cycle, Mutual funds, Price Sensitivity Jel codes: G11, G23

\section{Introduction}

Numerous contributions in literature have investigated investment behavior in the mutual fund market within the framework of optimal portfolio allocation: investors form expectations on performance and risk of different funds and optimally allocate their assets. Puzzles such as the growth of underperforming active funds or the insensitivity of investors to poor performances have been rationalized under the assumptions that investors dynamically forecast managerial ability

\footnotetext{
${ }^{1}$ Contact information: Finance Discipline Group, UTS Busienss School, The University Of Thechnology, Sydney. PO Box 123, Boradway, NSW 2007 Australia. Email: marco.navone@uts.edu.au. The author would like to acknowledge financial support from CAREFIN, the Centre for Applied Research in Finance of Bocconi University, Milan.
} 
incorporating information such as diminishing returns to scale (see for example Gruber, 1996 and more recently Berk and Green, 2004). Where information costs are explicitly considered (see for example Huang et al., 2007 and Del Guercio and Tkac, 2008) they are still analyzed within an optimal investment framework where investors have to costly acquire publicly available information in order to forecast expected returns.

The idea of mutual fund investing as a form of optimal portfolio allocation may appear excessively simplistic if we consider that mutual funds are not simply "investment opportunities" (i. e. dots in a mean-variance space) but "investment products" with recognizable brands, diverse distribution channels, more or less transparent pricing policies etc. In other words mutual funds share a number of similarities with consumer products.

In this paper I do not dismiss the idea that mutual funds are legitimate investment products ad that they are the object of (tentatively) rational asset allocation decisions. What I argue, instead, is that the demand function for mutual funds is more complex than what would be implied by a simple optimal asset allocation decision and that it's worthwhile to investigate whether mutual funds investors' behavior share some of the dynamics documented in literature for non-financial consumer products.

In a recently published article Keloharju et al. (2012) show that consumer habits can affect investment behavior. Using a unique dataset of Finnish families they show that consumption choices affect investment behavior as investors are more likely to invest in companies they frequent as customers. While this effect is still framed within an optimal allocation choice where consumption lowers the information acquisition cost on a specific stock, the article documents in a very convincing way that consumption and investment behavior are indeed deeply interconnected.

In this paper I follow a different approach and analyze whether the aggregate demand of equity mutual funds in the United States exhibits behaviors similar to what has been documented by empirical research in consumer goods markets. The dynamics of the business cycle offer an interesting environment for this analysis: Estelami et al. (2001) show that GDP growth is a prominent factor in determining consumers' price awareness: during recessions prices play a much stronger role 
in consumption decisions. The traditional approach to prices (expense ratios) in mutual fund research is expressed by the Christoffersen and Musto (2002) argument according to which from the investor's point of view the expense ratio is simply a negative component of the performance and thus performance sensitivity implies price sensitivity. Contrary to this, Navone (2012) documents different time-series and cross-sectional dynamics of price and performance sensitivity. Using nine different proxies for the economic environment in this paper I show that while changing macroeconomic conditions increase price sensitivity they do not systematically affect performance sensitivity.

A second main finding in consumer products research is that while the increased price awareness can be logically linked to lower disposable income during recessions, this change in consumption behavior seems to be motivated more by expectations concerning future hardship than by the current economic situation (Roche et al., 2010). Using different consumer sentiment indices designed to capture these two aspects of the macroeconomic environment I show that indeed the increased price awareness is more correlated with expectations concerning the evolution of the macroeconomic environment than with the current economic situation.

This is not the first study to look at time-factors that could affect mutual fund investors' demand function. In recent years different contributions have analyzed different channel thorough which the macroeconomic environment could affect investors' behavior: possible alternative explanation involve time-varying information content of mutual fund past performance (Kim, 2011 and Kacperczyk et al., 2012a and 2012b), time-varying risk aversion (Guiso et al., 2011) and a changing competitive environment with the increased availability of low-cost passive investment alternatives (Navone, 2012). I test these competitive explanations and show that while they general affect price and performance sensitivity in the predicted way they do not eliminate the main finding of this paper.

Lastly Lamey et al. (2007) and Gijsenberg et al. (2010) show that during recessions investors are more likely to abandon established brands and that advertising becomes less effective. Using a new dataset of advertising expenditures I show that while during tough times large funds and funds belonging to large investment complexes appear to be less attractive, hinting to a weakening of brand 
loyalty, advertising by mutual fund companies becomes more effective during recessions. I reconcile this contrasting result by showing that, contrary to common beliefs, investment companies with large advertising budgets charge lower expense ratios. While in literature expense ratios have been used as a proxy for advertising expenses (Sirri and Tufano, 1998) to the best of my knowledge no one has ever empirically tested this assumption. I show that higher advertising budgets are financed through increased volumes (asset under management) and not higher prices (expense ratios).

The rest of the paper is organized as follows: Section 2 contains a brief summary of the literature on consumers' behavior; Section 3 describes the data; Section 4 looks at the dynamics of investors' price-sensitivity across the business cycle; Section 5 explores a number of alternative hypothesis and documents the robustness of the main results; Section 6 looks at the effect of advertising on investment flows; Section 7 concludes.

\section{Literature Review}

In their effort to explain price dispersion in the context of money market funds, Christoffersen and Musto (2002) conclude that "from its investors' point of view, a fund's fee is simply a direct reduction of performance, so performance insensitivity implies price insensitivity". This implies that prices are not an independent decision variable but are simply a component of expected returns in the framework of optimal portfolio allocation. Contrary to this view Barber et al. (2005) show that investors react differently to periodic and one-time fees, hinting that there may be other factors at play. More recently Huang et al. (2007) and Iannotta and Navone (2012) show that investors' reaction is affected by their ability to acquire and process information. Survey and experimental evidence also show that investors do not consider fund expenses simply as a negative component of expected returns $^{2}$. All this evidence together suggests that mutual fund investing may have more in common with consumers' behavior in non-financial markets than what academic literature has so far acknowledged.

\footnotetext{
${ }^{2}$ See for example Capon et al. (1996), Wilcox (2003) and Choi et al. (2010).
} 
Looking at investment/buying decisions across the business cycle offers an interesting space to investigate to which extent mutual fund investors' behavior is similar to consumers' behavior documented in non-financial academic literature.

Estelami et al. (2001) survey 27 marketing studies and show that among the factors that affect consumer price awareness a prominent role is played by GDP growth rate: in period of strong economic growth consumers pay less attention prices.

Using data on the diffusion of low-cost private labels in the US, UK, Germany and Belgium from 1971 to 2004, Lamey et al. (2007) show that consumers are more likely to switch from a recognized brand to a low-cost alternative during tough economic times, and that consequently in these period the market share of these low cost alternatives increases.

Gijsenberg et al. (2010) estimate time-varying advertising and price elasticities for 163 brands, across 37 product categories, based on 15 years of monthly data from 1993 to 2007 in the UK and show that price sensitivity tends to increase during economic downturns, while advertising elasticity shows a decrease. Moreover, during contractions, consumers show less behavioral loyalty.

These studies provide support for two main hypotheses amenable to empirical testing in the context of mutual fund investing: as the economic environment worsen

1. Price sensitivity of investors should increase.

2. Brand and product loyalty should decrease.

An additional testable hypothesis comes from a survey on consumers' intentions conducted in the 2010 Boston Consulting Group Global Report on Consumer Sentiment (Roche et al, 2010) on 15000 households in 14 countries. According to this survey consumers' behavior seems to be influenced more by expectations regarding the evolution of future economic conditions than by the actual economic situation. So far in marketing research the evolution of the GDP seems to be the macroeconomic variable of choice. In this study, using a variety of economic indicators and consumer sentiment indices I will be able to address this issue more thoroughly. 
In the end is important to recognize that time-variation in investment behavior can be generated by factors other than the evolution of the economic environment.

Kim (2011) analyzes the evolution of performance sensitivity of mutual fund investment flows and shows that this quantity changes through time in response to changes in the information content of fund past performances. In period of high market volatility fund returns convey less information about managerial ability. Investors react rationally by decreasing their reliance on past performance in the fund selection process. The same happens when the cross-sectional volatility of fund returns is small. In an unrelated but logically connected work Kacperczyk et al. (2012a) find evidence of time-varying fund manager ability. Specifically they document significant stock selection ability during market booms, while market timing becomes more relevant during recessions. In a related work (Kacperczyk et al., 2012b) the same authors show that return predictability in the mutual fund industry varies across the business cycle. All this evidence bears no direct consequence for price sensitivity per se, but since expense ratios affect net performance we could capture a by-product of the reduced performance sensitivity.

Guiso et al. (2011) use a repeated survey of a large sample of clients of an Italian bank to measure possible changes in investors' risk aversion following the 2008 financial crisis. They find that both a qualitative and a quantitative measure of risk aversion increase substantially after the crisis, and that these changes are correlated with changes in portfolio choices. If we assume that fund expense ratios reflect, at least in part, the intensity of active management of the fund (for example higher cost of security analysis) we could expect a positive relation between prices and fund risk, and thus a change in price sensitivity as a response to a changing risk aversion.

Finally Navone (2012) documents a long term increase in price sensitivity in the last 15 years. Among the different explanations for this trend the author considers the diffusion of low-cost passive funds such as index funds and ETFs. The availability of low cost alternatives may increase the sensitivity of investors to expense ratios, especially in light of all the coverage that the issue of lack of active performance has received in specialized and popular press alike in the last years. 
For sake of completeness it is important to notice that the effect of the macroeconomic environment on financial choices has been previously addressed in a number of relevant contributions. Campbell and Cochrane (1999) propose a consumption based asset pricing model that addresses the relationship between asset prices and macroeconomics. Other financial decisions affected by the business cycle go from security issues (Choe et al., 1993) to capital structure decisions (Korajczyk and Levy, 2003), to loan pricing decisions (Santos and Winton, 2008). To the best of my knowledge no other paper has addressed the issue of mutual funds demand across the business cycle.

A number of contributions have also analyzed the issue of mutual fund advertising. Jain and Shuang (2000) analyze 294 funds that advertised in financial press and find that while this funds do not outperform a control sample of similar investment products the indeed attract higher investment flows. Looking at advertising by Swedish mutual fund companies around the privatization of the local pension system Cronqvist (2006) shows that while fund advertising has very poor informational content still positively affect investment flows. Reuter and Zitzewitz (2006) look at advertising from a different perspective and document a positive correlation between advertising expenditures and the tone of press coverage of mutual fund in specialized press. Finally Gallaher et al. (2008) use advertising data from 1992 to 2001 both at the family and the individual fund level and document a positive and convex relationship between advertising and investment flows. This last paper is the closest to my work in terms of use of advertising data as determinants of mutual fund flows, but they do not address the issue of advertising effectiveness across the business cycle.

\section{Data}

In this paper I use data from the CRSP Survivorship Bias Free Mutual Fund Database from 1991 to 2011 on US equity mutual funds with asset under management above 20 million dollars and age since inception above or equal to 36 months. According to Evans (2010) these two cutoffs allow to eliminate fund shares in their incubation period where investment flows are not driven by investors demand. 
A significant portion of prior research on mutual fund flows has been focused on equity funds ${ }^{3}$. In the context of the present article this restriction is particularly sensible since price sensitivity is more likely to be relevant for equity funds where expense ratios are higher. In an unreported analysis I've extended the experiments of this paper to a larger sample of equity, bond and money market funds. All the major results hold albeit statistically weaker.

Some fund characteristics, such as performance, expense ratio and volatility (as well as investment flows), changes significantly across investment objective. In this analysis the value of these variables is normalized within each investment objective / time period. I consider both the more parsimonious industry classification provided by Thomson-Reuters Mutual Fund Holdings database ${ }^{4}$ where all domestic equity funds are divided into three categories (Growth and Income, Growth and Aggressive Growth) and the more granular CRSP classification ${ }^{5}$ with 21 detailed investment objectives. Results with the two classifications are indistinguishable. Results in the paper are based on the ThomsonReuters classification.

After 1999 CRSP correctly classify index funds and fund shares sold to institutional investors. Prior to this date, in order to consistently identify these observations I follow Gil-Bazo and Ruiz-Verdú (2009) procedure for individuating index and institutional fund shares from the reported name ${ }^{6}$. Since CRSP does not report data on fund affiliation to management companies prior to 1999 , and since familylevel factors are important determinants in investment flows ${ }^{7}$, family affiliation data is from Thomson-Reuters.

Table 2 reports summary statistic for the sample.

\footnotetext{
${ }^{3}$ See for example Sirri and Tufano (1998), Huang et al. (2007) and Gil-Bazo and Ruiz-Verdú (2009).

${ }^{4}$ This database is formerly known as CDA/Spectrum.

${ }^{5}$ I consider the newly introduced CRSP Objective Code (crsp_obj_cd) that provides a unified code consistent through time.

${ }^{6}$ A fund is considered an index fund if the name contains any of the following strings: "Index," "Idx," "Ix," "Indx," "NASDAQ," "Nasdaq," "Dow," "Mkt," "S\&P 500" or "BARRA." In the same way a fund is considered institutional if the name contains "Inst" or "inst" or if it belongs to share classes "Y" or "I."

${ }^{7}$ See for example Kempf and Ruenzi (2008).
} 


\subsection{Macroeconomic Conditions}

In order to model macroeconomic conditions I employ a variety of indicators that can be roughly divided into two categories: business cycle indicators and sentiment survey data.

For the first group I consider the NBER recession indicator, the change in Industrial Production and the level of capacity unitization from the Federal Reserve Board. I also include the change in the Coincident Economic Activity Index that is a composite index calculated by the Federal Reserve Bank of Philadelphia based on four indicators: nonfarm payroll employment, the unemployment rate, average hours worked in manufacturing and wages and salaries. Finally I consider the Leading Index for the United States. This variable, also calculated by the Federal Reserve Bank of Philadelphia predicts the six-month growth rate of the coincident index. In addition to the coincident index, the model includes other variables that lead the economy: state-level housing permits ( 1 to 4 units), state initial unemployment insurance claims, delivery times from the Institute for Supply Management (ISM) manufacturing survey, and the interest rate spread between the 10-year Treasury bond and the 3-month Treasury bill. All the variables are expressed quarterly as the average of the three monthly values. For the NBER indicator a quarter is considered recessionary if at least one month in the quarter is a recession month.

A second group of variables considers surveys of "sentiment" that capture the perception of the economic environment more than the environment itself. Specifically I consider:

- The University of Michigan Consumer Sentiment Index (also known as the Thomson Reuters/University of Michigan Surveys of Consumers). This index is calculated monthly and it's based on the answer to five core questions in 500 telephone calls to consumer in continental United States. The five questions investigate the perception of the current economic conditions (as opposed to one year before) and the expectation on the future evolution of said conditions (over the next twelve months). 
- The Conference Board Consumer Confidence Index. This index is calculated monthly based on a larger sample of 5000 households. In this case the index also has two components, one focused on present conditions (40\% of the index) and one based on future expectations (60\%).

- The NFIB Small Business Optimism Index calculated monthly by the National Federation of Independent Business. The NFIB is the largest small business advocacy group in the United States. All the associates are polled monthly on a range of issues. The Optimism Index captures expectations over the evolution of the business environment over the next quarter.

- The Washington Post-ABC News Consumer Comfort Index based on telephone interviews with 1,000 randomly selected adults nationwide conducted over the previous four-week period. The index is based on three core questions. These questions ask respondents to rate the condition of the national economy, the state of their personal finances and whether now is a good time to buy things.

Data on all these surveys are taken from Bloomberg. Table 3 reports the average values for all the continuous macroeconomic proxy variables during the subsamples of expansion and recession quarters. As expected all the proxies exhibit a significantly lower value during "tough" economic times. Table 4 shows the correlation coefficients among the macroeconomic variables. All the consumer surveys are highly correlated among themselves while the continuous macroeconomic indicators are positively correlated among themselves but to a lesser extent. These surveys, in turn, are only weakly correlated with the business cycle indicators. Of course all the continuous indicators are negatively correlated with the binary recession indicator variable that has a value of one for recession and zero for expansion quarters. Overall this analysis shows that while all the variables capture the common idea of "tough" and "good" times, the differences are significantly enough to suggest that they may capture different aspects of the macroeconomic environment. Some indicators are more contemporaneous with the business cycle while others are more forward-looking, moreover the survey data capture the perception of the macroeconomic environment rather that the environment itself. The consideration of the different variables will increase the robustness of this analysis and 
allow some additional insights on the effect of the macroeconomic environment on the behavior of mutual fund investors.

In order to make interpretation of the results easier, all the macroeconomic factors are expressed so that an increase in the indicator stands for a worsening of the macroeconomic environment, and variables that are naturally increasing in quality are multiplied by minus one.

\section{Price Sensitivity and the Macroeconomic Environment}

The basic model is a regression of net investment flows over past performance and expenses as well as over a number of control variables that have been proven relevant in previous literature.

$$
\text { Flow }_{i t}=\alpha+\boldsymbol{\beta} \Gamma+\varepsilon
$$

Where Flow $_{i t}$ is the net investment flow defined as the percentage growth of total net assets (TNA) adjusted for the fund return net of expenses $\left(r_{i t}\right)$ :

$$
\text { Flow }_{i t}=\frac{T N A_{i t}-T N A_{i t-1}\left(1+r_{i t}\right)}{T N A_{i t-1}}
$$

Flows are calculated on a monthly basis and aggregated over each quarter in order to minimize the approximation errors due to the timing of investment decisions. The choice of the quarterly level for my analysis is the result of a tradeoff between being able to measure the response to a dynamic economic environment and acknowledging that investment decisions take time and there is a measurable degree of inertia as indicated by the significant serial correlation of investment flows ${ }^{8}$.

In model (1) $\Gamma$ is a vector of explanatory variables that contains:

\footnotetext{
${ }^{8}$ In an unreported monthly-level analysis all the main results are confirmed. A yearly level analysis as presented in other mutual fund papers (see for example Sirri and Tufano, 1989) would be inappropriate here due to the significant changes in the macroeconomic environment that could be experience in a 12 -months period.
} 
Past Performance: as the performance measure I consider the fund's after expenses total return normalized within each investment objective/quarter by subtracting the cross-sectional average return and dividing by the cross-sectional standard deviation of the returns. In order to model the wellknown nonlinear relationship between flows and performance I use the specification introduced by Gil-Bazo and Ruiz-Verdú (2009) and include two dummy variables (Mid and High) for funds whose performance is in middle and top third of their investment objective distribution.

Expenses: I consider the total expense ratio (Exp) normalized within each quarter/investment objective. The normalization avoids biases due to differences in expense ratios between investment objectives and time trend in expense ratios.

I also include a group of variables to control for relevant fund characteristics: the (natural log of) fund asset under management at the end of the previous quarter (Size), the (natural log of) fund age in months (Age), a dummy variable equal to 1 if the fund share is no-load ${ }^{9}$ (No Load), a dummy variable for institutional fund shares (Institutional), the fund standard deviation of monthly returns over the previous year normalized within each quarter/investment objective (St. Dev.). I also include the (natural log of) fund asset under management of the investment company at the end of the previous quarter (IC Size) and the asset weighted average investment flow in other funds managed by the same investment company (IC Flow). As before, this last variable will capture factors at the investment company level, such as proprietary distribution channels and reputational issues. In some specifications I also include the lagged value of net investment flows (Flow $\left.w_{t-1}\right)$ to capture the stickiness of investment flows. This variable will be later dropped as it does not affect the results.

Table 5 reports the results of the estimation of the basic model using three different estimation methodologies: OLS, Panel regression with fund fixed effects and Fama-MacBeth (1972) repeated cross-sectional estimation. In the first two specifications the standard errors are clustered at the fund level. All the coefficients are fairly stable across the different estimations and coherent with the

\footnotetext{
${ }^{9}$ Defined as no front or back-end load and $12 \mathrm{~b}-1$ fees below $1 \%$.
} 
results in previous literature ${ }^{10}$. Investment flows exhibit a positive and convex relationship with past performance as well as a negative and significant relationship with expense ratios and volatility. The results also show a strong investment company effect. Finally the presence of the lagged flow does not alter the significance of the other covariates.

\subsection{Investment flows and macroeconomic conditions}

Table 6 shows average (normalized) investment flows in funds with different characteristics (performance, risk and expense ratios) in "good times" and "tough times" defined as the top and bottom thirds of the distribution of changes in the US Coincident Index (Panel A) and of the Consumer Sentiment Index (Panel B). Results show that cheap funds (bottom quintile of the normalized expense ratio distribution) do not experience any particular advantage over expensive funds (top quintile) in good times: both groups have average normalized investment flow close to zero (an unadjusted expense ratio close to the sample mean for a specific quarter/investment objective). The situation changes in tough times when expensive funds are strongly penalized while cheap funds benefit from higher than the average flows. This simple univariate result indicates that price sensitivity, as expected, is higher during tough economic times. It is important to note that this is not a side effect of time-varying performance sensitivity (as the Christoffersen and Musto argument would imply): while top performing fund experience high investment flows than the worst performing funds irrespective of the macroeconomic environment, it's clear that their comparative advantage becomes weaker during tough economic times, when performance sensitivity of investment flows decreases. Finally the table also shows that risk sensitivity increases during tough economic times.

To overcome the intrinsic limitation of this univariate analysis I will run the following augmented version of the basic regression model

$$
\text { Flow }_{i t}=\alpha+\boldsymbol{\beta} \Gamma+\delta C+\lambda[C \times \Gamma]+\varepsilon
$$

\footnotetext{
${ }^{10}$ Results in the remaining of the paper will be based on the panel specification with fixed effects.
} 
where $C$ is the macroeconomic variable of interest. The vector of the interaction coefficients $\lambda$ captures the changes in investors' behavior induced by changes in the economic environment.

Table 7 reports these interaction coefficients and confirms the main findings of the univariate analysis. Specifically the results show that consistently with mainstream consumer goods research, investors react to tough times by turning away from expensive products. All the interaction coefficients with the normalized expense ratio are negative and highly significant, meaning that the (negative) relationship between investment flows and prices becomes stronger as the macroeconomic environment deteriorates. The magnitude of this effect is also relevant: an increase of the expense ratio of one standard deviation (the actual increase would be different for each investment objective) would generate a negative net investment flow of $-4.8 \%$ of the total size of the fund in an expansionary period, but in a NBER recession the fund would lose $13.44 \%$ of its net asset value. Again it's possible to see that this is not a side effect of increased performance sensitivity, in fact sensitivity of investment flows to performance (and its convexity) decreases in "tough times".

A second key result is that positional rents like brand loyalty seem to be less relevant in the decision process during recessionary periods: although there is no direct proxy for "brand strength" in this regression results show that large funds and funds managed by large investment companies are more heavily penalized in terms of net investment flows during period with negative macroeconomic outlook. Also the coefficient of IC Flow, the variable that captures the flows to other funds of the same family is negative albeit only for the interaction with consumer sentiment surveys.

All these results show that during tough times investors re-evaluate investment choices and focus the decision process on individual fund characteristics, principally the investment cost, while positional rents become less relevant.

\subsection{Present conditions and expectations about the evolution of the economic environment}

Macroeconomic conditions affect consumers' behavior both via a direct wealth effect and via changes in expectations concerning future income and wealth. In the 2010 Boston Consulting Group Global Report on Consumer Sentiment (Roche et al, 2010), 15000 consumers from 14 countries were 
surveyed on their buying intention for 70 products categories ranging from apparel and footwear to cars and vacation travels. The authors of the research concluded, among other things, that "Consumer spending is a function of real and perceived wealth as well as actual buying power" and that "Reaction to the crisis were, for many, driven more by anticipation of personal and economic hardship than by the actual experience of any hardship".

It seems, thus, that the specification of the measure used to capture the evolution of the economic environment may be crucial in order to capture consumers' / investors' reaction. My setting offers a natural way to further investigate this issue thanks to the fact that the University of Michigan Survey of Consumer Confidence Sentiment and the Conference Board Consumer Confidence Index are both built by aggregating sub-indices that capture the present economic situation and expectations on future economic conditions. I use these sub-indices as two competing macroeconomic factors in an estimation of model (4) where $C$ and $D$ are the two competing time-related factors capturing the current economic situation and the expectations concerning the evolution of the macroeconomic environment.

$$
\text { Flow }_{i t}=\alpha+\boldsymbol{\beta} \boldsymbol{\Gamma}+\delta C+\lambda[C \times \boldsymbol{\Gamma}]+\theta D+\boldsymbol{\pi}[D \times \boldsymbol{\Gamma}]+\varepsilon
$$

As a robustness I also run this model considering (changes of) the US Coincident Index and the US Leading Index as two competitive time-related factors. The Leading Index is designed to forecast 6month changes of the Coincident Index and thus can be considered as a measure of expectations about the evolution of the economic environment, while the change in the coincident index captures the current economic situation. Figure 1 shows the three couples of variables.

The coefficients of the interaction terms $(\lambda$ and $\pi)$ in Table 8 show that indeed the increase in price sensitivity is mainly due to a worsening in the expectations concerning future economic conditions. The interaction term between expense ratio and the time-related variables designed to capture the current economic situation is negative and significant only in one case out of three and even in this case the magnitude is much smaller than the relative future situation variable. 
So not only price sensitivity increases in the mutual fund market during tough times as it does in consumer goods market, but it also seems that the drivers behind this increase are the same.

\section{Alternative Explanations}

Other time-related factors could affect mutual fund investors' behavior. In this section I will analyze three possible factors that have been studied in previous literature: time-varying information content of past performance, risk aversion and competition from low-cost passive investment products.

I address this issue using the framework of regression model (4) where now $C$ is one of my nine macroeconomic environment proxy variables and $D$ is a proxy variable for the relevant competitive explanation.

A first alternative explanation concerns time-varying information content of past returns. If investors perceive mutual fund past performance as less informative the weight of this factor in the fund selection process could decrease and this would in turn increase the sensitivity of investment flows to other factors, for example expense ratios. Kim (2011) shows that investment flows sensitivity to past performance decreases when performance is less informative about managerial ability. The author argues that in a highly volatile environment mutual fund returns carry little information about the fund manager ability. The same happens when cross-sectional variation of fund returns is small and the smaller differences become less indicative of differential managerial ability. There is no direct prediction of any effect of these variables on investors' price sensitivity, but as mentioned before if investors rely less on past performance in the selection process the weight of expense ratios could increase.

I test the relevance of this hypothesis in two specifications of model (4) where the competing variable $D$ is the 12-months volatility of the CRSP VW Market Index or the cross-sectional volatility of quarterly fund returns (within each investment objective). Panel A of Table 9 shows the estimated coefficient for the interaction between the normalized expense ratio and the two couples of competing time-related factors. Results show that the inclusion of this competing hypothesis in the model does 
not weaken the effect of the macroeconomic environment on investors' price-sensitivity. Interestingly the interaction between expense ratios and both proxies for lack of information content of past returns is positive, indicating a reduction of price sensitivity. To the extent that expense ratios affect fund performance this result would be consistent with Kim (2011).

A second possible alternative explanation relies on evidence of time-varying risk aversion: if investors' attitude varies across the business cycle lower investment flows into risky funds during tough times could generate a spurious increase in price-sensitivity, provided that there is an empirically proved positive relationship between expense ratios and fund volatility (see Gil-Bazo and Ruiz-Verdú, 2009 and Iannotta and Navone, 2012). Guiso et al. (2011) show that risk aversion of retail investors has significantly changed following the 2008 crisis. The post-crisis period is a small portion of my database but the idea that time-varying risk aversion could affect investors' behavior is worth investigating.

Following Guiso et al. (2011) and Friend and Blume (1975) I infer relative risk aversion from the share of investments in risky assets. In Merton's (1969) portfolio model, the share of the portfolio allocated to risky assets by an individual is

$$
\alpha=\frac{r}{\theta \sigma^{2}}
$$

Where $r$ is the expected equity premium, $\sigma^{2}$ is the variance of the risky asset and $\theta$ is the relative riskaversion coefficient. Under the assumption that investors share expectations about return and risk the risk aversion is

$$
\theta=\frac{r}{\alpha \sigma^{2}}
$$

I implement this measure of risk aversion using the CRSP Value Weighted total return index minus the 30 days Treasury bill as a measure of excess return of the risky asset. Each quarter investors form their expectations looking at average return and variance from January 1925 to the beginning of the quarter. Allocation in the risky asset is proxied by the ratio of equity directly and indirectly held by 
US Households as a proportion of their total financial assets ${ }^{11}$. Figure 2 shows that albeit highly imperfect this rough measure of risk aversion seems to capture the effect of the global financial crisis (and of the economic outlook in general) on the attitude of investors toward risk.

Panel B of Table 9 shows the results of an estimation of model (4) where the alternative time-related variable is the risk aversion at the beginning of the quarter. Again this alternative explanation seems unable to explain the increase of price sensitivity during tough times. In fact time-varying risk aversion seems not to affect price sensitivity in any consistent way across the nine different specifications.

A third variable that could affect investors' price sensitivity is the time-varying intensity of price competition in the US mutual fund market. During the period analyzed in this paper the availability of low-cost passive investment products such as index funds and ETFs has grown from virtually zero to a significant portion of the mutual fund industry (see Agapova, 2011). Navone (2012) documents a long-term increase in price sensitivity coincident with this shift in the competitive structure of the market and one could argue that the availability of low-cost alternatives has increased the price awareness of investors. I test this effect using as a proxy for the intensity of price competition in each industry segment the market share of index funds in terms of asset under management (within each investment objective). Panel $\mathrm{C}$ of Table 9 shows that while indeed the presence of low-cost alternatives increases investors' price sensitivity consistently across all specifications this adds to, rather than substitute, the effect of the macroeconomic outlook.

\section{Advertising}

Like firms in other industries investment companies may invest in advertising to attract clients/investors for their mutual funds. Sirri and Tufano (1998), Huang et al. (2007) and Iannotta and

\footnotetext{
${ }^{11}$ Data is from the Flow of Funds Accounts of the United States (B.100e form). In an unreported alternative formulation I also consider the ratio of equity to total assets. The results are indistinguishable.
} 
Navone (2012) argue that investors incur in search costs when they have to choose a mutual fund. Investment companies may lower these costs by investing in advertising and delivering relevant information to prospective clients.

Two studies have looked at the information content of mutual fund advertising. Jain and Wu (2000) look at advertising by a small sample of mutual funds in two major financial publications and conclude that while these funds exhibit strong pre-advertisement performance they do not exhibit post-advertisement superior performance. Using a sample of Swedish mutual funds Cronqvist (2006) analyzes the information content of mutual fund advertising concluding that only a fraction of advertising is informative about relevant characteristics such as expense ratios or past performance. Interestingly both studies show that even if their information content is questionable, advertising has a significant effect on investment flows ${ }^{12}$.

Due to data limitation the direct evidence on the effect of advertising on the behavior of investors is still limited. Sirri and Tufano (1998) Khorana and Servaes (2012), Barber et al. (2005) use mutual fund fees (either the total expense ratio or the 12b-1 component) as a proxy for marketing expenses. To the best of my knowledge the only paper that considers a comprehensive database of mutual fund advertising is Gallaher et al. (2008). The authors use data on print advertising both at the investment company and at the individual fund level from 1992 to 2001 on all mutual fund families with at least 1 b\$ of asset under management. They conclude that advertising affect investment flows both at the individual fund and at the family level.

In this paper I use a more complete database of mutual fund advertising from 2001 to 2010. Nielsen Monitor-Plus ${ }^{\mathrm{TM}}$ collects monthly data on advertising by investment companies in 20 different media ranging from television (both cable and network, national and regional, English- and Spanishspeaking), to radio (both national networks and local), press (national and local, magazines and newspaper, Sunday supplements and free-standing inserts), internet (national and local), outdoor

\footnotetext{
${ }^{12}$ On a slightly tangential topic Reuter and Zitzewitz (2006) show that mutual fund advertising can affect editorial content of financial press, specifically they find that mutual fund recommendations are correlated with past advertising in a number personal finance publications, They attribute this effect to the conflict of interest of editors interested in attracting advertising budget, more than to the information content of the advertising itself.
} 
billboards and business-to-business specialized press. Appendix 1 contains a complete list of the sources.

Investment companies are matched by name, case of dubious or unclear matching are dropped. Table 10 contains descriptive statistics for this subsample. The data cover $38.5 \%$ of the investment companies, accounting for $73.4 \%$ of the funds and $88.2 \%$ of the assets under management.

The total advertising budget has decreased sharply from $354 \mathrm{~m} \$$ in 2001 to $123.5 \mathrm{~m} \$$ in 2010 . Although quantities (measured in "units") do not show a similar decline, hinting to a reduction in the price per unit, these numbers have to be taken with caution as the definition of "unit" is not consistent across different media and the table shows a significant shift in the mix of media in the latter part of the sample, with a sharp increase of internet and business-to-business advertising.

Table 11 looks at characteristics of investment companies with total advertising expenditures over the entire period above or below the industry median. Panel A considers the unadjusted expenditures while in Panel B expenditures are divided by the asset under management of the company. Highadvertising companies tend to be larger (not surprisingly) and to manage larger and older funds ${ }^{13}$. Looking at individual fund characteristics we see that high advertisers manage, on average, funds with lower risk and return. Finally we can see that investment companies with unadjusted advertising expenditures above the median also manage funds with lower (investment objective adjusted-) expense ratio. This last evidence is a bit counterintuitive as it is usually assumed that higher advertising budget is financed with higher expense ratios. Sirri and Tufano (1989) specifically use the expense ratio as a proxy for the marketing budget (implicitly assuming a positive correlation), and Gallaher et al. (2008) document a positive relationship, albeit with a database that covers only print advertising and in an older period. This counterintuitive result can be explained if we consider that high advertisers tend to be larger in terms of asset under management, and that high advertising budgets can be financed through larger volumes rather than higher prices. In Panel B high and low advertisers are defined based on a measure of expenditures per dollar of asset under management.

\footnotetext{
13 This evidence corroborates the intuition of Huang et al. (2007) and Iannotta and Navone (2012) that investment company size and fund size and age are proxies for mutual fund visibility.
} 
Results show that when with this adjustment high advertisers indeed charge a higher expense ratio (with the difference being significant when we consider the value net of $12 b-1$ fees).

In spite of this explanation it's important to consider that the assumption according to which high visibility through advertising comes to a price in terms of high expense ratios is fundamentally flawed as large investment companies can sustain high levels of advertising through sheer volumes and still charge lower expense ratios.

A fundamental question at this point is whether higher advertising leads to higher investment flows. In Table 12 I run the basic flow model (Equation 1) where among the explanatory variable I add the (natural log of) advertising budget or the investment company share of total industry advertising in the quarter. Results consistently show that the increased visibility provided by advertising expenditures lead to higher investment flows. Advertising can make investors more aware of funds salient characteristics, such as prior performance and investment costs. In the same Table I also interact the advertising budget with past performance and/or expense ratio and show that while high advertising reduces performance sensitivity it also increase price-sensitivity (at least when we consider the share of advertising in the quarter).

This result is consistent with Navone (2012) where the author considers other proxies for fund visibility such as fund size and age or size of the investment company, and supports the idea that improved visibility helps investors to make decision based on pieces of information that are not easy to acquire: expense ratios are normally to be found in fund prospectuses whereas the past performance for mutual funds is easily obtainable from newspapers and online rankings.

Admittedly a potential weakness of this experiment is that while flows are at the fund share level, advertising is at the investment company level. While it is reasonable to assume that advertising increases brand awareness and thus visibility for all the funds in the family, it is also possible that a company may decide to promote a specific product, and in this case the advertising may not benefit other mutual funds in the same family. Gallaher et al. (2008) look at expenditures both at the family level and at the individual fund level and show that both affect investment flows, but they do not test 
the two variables in the same model so it's not possible to test whether the two effects overlap. It is certainly possible that my results are partially biased by other family-related factors, but the fixed effect specification should at least minimize this problem as stable family-level factors related, for example, to specific distribution channels, would be captured by the fund-specific intercepts.

\subsection{Advertising in tough times}

While there is a generally accepted view in marketing research on the increase of price awareness during tough times the same is not true for the effectiveness of advertising.

On the one hand, since advertising volumes drop during recessions (Deleersnyder et al., 2009) one could expect an increase in effectiveness due to a reduction in saturation (Danaher et al., 2008). On the other hand, it has been argued that during recessions consumers focus more on prices and functional aspects of products, (Gijsenberg et al., 2010).

Empirical evidence is also mixed: Frankenberger and Graham (2003) find that advertising expenditures during tough times are associated with stronger financial results in terms of operating income and shareholders' value. Similarly Deleersnyder et al. (2009) shows that pro-cyclicality in advertising expenditures has a negative impact on stock-price performance. On the opposite side a recent working paper by Gijsenberg et al. (2010) directly measure advertising effectiveness across the business cycle and shows a sharp decrease.

I investigate this issue by estimating a specification of equation (3) where advertising is included among the covariates and interacted with the different macroeconomic proxy variables. Table 13 shows the results of this estimation for the (log of) advertising budget (Panel A) and the market share of advertising (Panel B). The sign and significance of the interaction coefficients show that advertising effectiveness increases in tough times only when we consider, as a macroeconomic indicator, consumer sentiment surveys, the interactions with business cycle indicators (Models 1 to 5) are inconsistent and often insignificant. 
While the general approach of this paper is to match some intuitions developed in marketing research with data in the mutual fund market, the empirical methodologies in the two research fields are quite different and this makes the discussion of the consistency of the results across industries somewhat complicated. The fact that I do not find a clear pattern in the dynamics of advertising effectiveness across the business cycle is somewhat consistent with the general lack of a shared empirical result in marketing literature. On the other side I also show that when the perception of the macroeconomic environment deteriorates advertising clearly becomes more effective. This does not come as a surprise in the light of three previously demonstrated empirical evidences: a) advertising increases investors' price sensitivity; b) price sensitivity increases in tough times and c) investment companies that advertise more also tend to charge lower expense ratios.

Advertising lowers the costs prospective investors have to pay in order to acquire information on salient fund characteristics, such as expense ratios, increasing the weight of these variables in the fund selection process. In tough times investors pay more attention to prices and thus advertising becomes more valuable.

\section{Conclusions}

In financial academic literature mutual fund investment has been studied from the perspective of an optimal portfolio allocation problem. In the last years an increasing body of empirical and experimental evidence has suggested that the behavior of investors in the mutual fund industry shares remarkable similarities with the behavior of buyers in consumer goods markets. In this study develop and test a number of hypotheses based on empirical evidence in marketing literature.

First of all I show that as the macroeconomic conditions deteriorate investors' price sensitivity increases while their brand loyalty decreases. Using comparative static I show that the increase in price sensitivity is economically significant, and I also show that, consistently with survey data on consumers' behavior, this effect is mainly driven by expectations of future economic hardship rather than by the current economic situation. 
Second, I show that this increase in price sensitivity due to changing macroeconomic conditions is robust to the consideration of three alternative hypothesis developed in previous literature based on time-varying risk aversion, informativeness of prior performance and competition from low-cost passive funds.

Lastly I employ a new database of advertising expenditures by mutual fund companies across 20 different media and, after documenting a number of new empirical facts on mutual fund advertising (such as the fact that advertising is paid through higher volumes rather than higher expense ratios), I show that the effectiveness of these expenditures increases when the perception of the economic environment worsens, but not then the actual macroeconomic conditions deteriorate.

Overall in this paper I show that investors' behavior in the mutual fund market shares remarkable similarities with that of consumers in non-financial industries, and that there are important insights to be gained by looking at the fund selection process through the wider lenses of a consumer choosing among a growing number of similar products and not only through the more traditional approach of an investor solving an optimal portfolio allocation problem. 


\section{Appendix 1}

\begin{tabular}{|c|c|}
\hline Medium & Sample \\
\hline 1. Network TV & $\begin{array}{l}6 \text { networks (ABC, NBC, CBS, UPN \& WB 1/95-9/06; PAX/ION, MNT } \\
\text { 9/5/06-10/28/09; CW since 9/18/06) }\end{array}$ \\
\hline 2. Cable TV & 94 networks \\
\hline 3. Syndication TV & $200+$ programs per month \\
\hline $\begin{array}{l}\text { 4. Spanish Language Network } \\
\text { TV }\end{array}$ & $\begin{array}{l}5 \text { Networks (Telemundo \& Univision, Telefutura since 7/02, Azteca since } \\
1 / 06 \text {, MTV Tr3s since 10/07, Estrella since 8/10) }\end{array}$ \\
\hline 5. Spanish Language Cable TV & $\begin{array}{l}7 \text { networks (Galavision since 10/02, Fox Deportes since } 1 / 07 \text {, MUN2 since } \\
\text { 9/07, Discovery En Español since 2/08, ESPN Deportes since 4/08, GoITV- } \\
\text { since 12/08, Tr3s since 6/10) }\end{array}$ \\
\hline 6. Spot TV & 210 DMAs (Designated Market Areas) \\
\hline 7. Local / Regional Cable TV & 51 DMAs \\
\hline 8. Network Radio & 3 networks (Citadel Media, Westwood, Premier) \\
\hline 9. Local Radio & $\begin{array}{l}39 \text { DMAs ( } 18 \text { in } 1 / 97 \text {,added } 1 \text { in } 5 / 01,1 \text { in } 1 / 04,1 \text { in } 5 / 04,5 \text { in } 1 / 05,13 \text { in } \\
1 / 06 \text { ) }\end{array}$ \\
\hline 10. National Magazine & 200+ Magazines \\
\hline 11. Local Magazine & 72 Magazines in 42 Top DMAs \\
\hline 12. National Newspaper & 3 newspapers (WSJ, USA Today, New York Times National Edition) \\
\hline 13. Local Newspaper & 121 newspapers in 58 Top DMAs \\
\hline 14. National Sunday Supplements & 9 Sunday supplements \\
\hline 15. Local Sunday Supplements & 8 Sunday supplements within 50 Top DMAs \\
\hline 16. Free Standing Inserts & 126 newspapers within 78 Top DMAs \\
\hline 17. Outdoor & $150+$ DMAs \\
\hline 18. National Internet & $\begin{array}{l}\text { Beginning with January } 2006 \text { data all advertisers are available. Prior to } 2006 \\
\text { the data set was; the Fortune } 1000 \text { companies, Top } 500 \text { traditional media } \\
\text { spenders, the Top } 75 \text { on-line spenders, the largest online publishers, and the } \\
\text { top e-commerce sites (since } 1 / 02 \text { ); Fortune } 500 \text { companies (since } 1 / 01 \text { ) }\end{array}$ \\
\hline 19. Local Internet & 79 DMAs \\
\hline 20. Business To Business & $600+$ magazines \\
\hline
\end{tabular}




\section{References}

Agapova, A., 2011, Conventional mutual index funds versus exchange-traded funds, Journal of Financial Markets, 14(2), pp. 323-343.

Barber, B., T. Odean and L. Zheng, 2005, Out of Sight, Out of Mind: The Effects of Expenses on Mutual Fund Flows, Journal of Business, 78(6), pp. 2095-2119.

Berk, J. and R. Green, 2004, Mutual Fund Flows and Performance in Rational Markets, Journal of Political Economy, 112(6), pp. 1269-1295.

Campbell, J., and J. Cochrane, 1999, By force of habit: a consumption-based explanation of aggregate stock market behavior, Journal of Political Economy, 107(2), pp. 205-251.

Capon, N., G. Fitzsimons and R. Prince, 1996, An individual level analysis of the mutual fund investment decisions, Journal of Financial Services Research, 10(1), pp. 59-82.

Christoffersen, S. and D. Musto, 2002. Demand curves and the pricing of money management, Review of Financial Studies, 15(5), pp. 1499-1524.

Choe, H., R. Masulis and V. Nanda, 2003, Common stock offerings across the business cycle: Theory and evidence, Journal of Empirical Finance, 1(1), pp. 3-31.

Choi, J., D. Laibson and B. Madrian, 2010, Why does the law of one price fail? An experiment on index mutual funds, Review of Financial Studies, 23(4), pp. 1405-1432.

Cronqvist, H., 2006, Advertising and portfolio choice, Unpublished manuscript, Ohio State University.

Danaher, P., A. Bonfrer, and S. Dhar, 2008, The Effect of Competitive Advertising Interference on Sales for Packaged Goods, Journal of Marketing Research, 45(2), pp. 211-25.

Deleersnyder, B., J. Steenkamp, and P. Leeflang, 2009, The Role of National Culture in Advertising's Sensitivity to Business Cycles: An Investigation across Categories, Journal of Marketing Research, 46(5), pp. 623-36.

Del Guercio, D. and P. Tkac, 2008. Star Power: The Effect of Monrningstar Ratings on Mutual Fund Flow, Journal of Financial and Quantitative Analysis, 43(04), pp. 907-936,

Estelami, H., D. Lehmann and A. Holden, 2001, Macro-Economic Determinants of Consumer Price Knowledge: A Meta-Analysis of Four Decades of Research. International Journal of Research in Marketing, Vol 18 (4). pp 341-355.

Evans, R., 2010, Mutual Fund Incubation, Journal of Finance, 65(4), pp.1581-1611.

Frankenberger, K. and R. Graham, 2003, Should Firms Increase Advertising Expenditures During Recessions?, MSI Working Paper 03-115, Marketing Science Institute, Cambridge MA.

Friend, I. and M. Blume, 1975, The demand for risky assets, The American Economic Review, 65(5), pp. 900-922.

Gallaher S., R. Kaniel and L. Starks, 2008, Advertising and Mutual Funds: From Families to Individual Funds, Unpublished manuscript, University of Texas. 
Gil-Bazo, J., Ruiz-Verdú, P., 2009. The relation between price and performance in the mutual fund industry, Journal of Finance, 64(5), 2153-2183.

Gijsenberg, M., H. van Heerde, M. Dekimpe and J. Steenkamp, 2010, Price and Advertising Effectiveness Over the Business Cycle, Unpublished manuscript, Louvain School of Management.

Guiso, L., P. Sapienza and L. Zingales, 2011, Time Varying Risk Aversion, Unpublished manuscript, European University Institute.

Gruber, M., 1996, Another Puzzle: The Growth in Actively Managed Mutual Funds, Journal of Finance, 51(3), pp. 783-810.

Huang, J., K. Wei and H. Yan, 2007. Participation costs and the sensitivity of fund flows to past performance. Journal of Finance, 62(3), 1273-1311.

Iannotta, G. and M. Navone, 2012, The Cross-section of Mutual Fund Fees dispersion, Journal of Banking and Finance, 2012, 36(3), pp. 846-856.

Kacperczyk, M., S. van Nieuwerburgh and L. Veldkamp, 2012a, Time-Varying Fund Manager Skill, Journal of Finance, forthcoming.

Kacperczyk, M., V. Glode, B. Hollifield, and S. Kogan, 2012b, Time-Varying Predictability in Mutual Fund Returns, NBER Working Paper 15038.

Keloharju, M., S. Knüpfer and J. Linnainmaa, 2012, Do Investors Buy What They Know? Product Market Choices and Investment Decisions, Review of Financial Studies, 25(10), pp. 29212958.

Kempf, A. and S. Ruenzi, 2008, Tournaments in Mutual-Fund Families, Review of Financial Studies, 21(2), pp. 1013-1036.

Khorana, A. and H. Servaes, 2012What Drives Market Share in the Mutual Fund Industry?, Review of Finance, 16(1), pp. 81-113.

Kim, M., 2011, Changes in Mutual Fund Flows and Managerial Incentives, Unpublished manuscript, University of New South Wales.

Korajczyk, R. and A. Levy, 2003, Capital structure choice: macroeconomic conditions and financial constraints, Journal of Financial Economics, 68(1), pp. 75-109.

Jain, P. and J. Wu, 2000, Truth in mutual fund advertising: Evidence on Future performance and fund flows, Journal of Finance, 55(2), pp. 937-958.

Lamey, L., Deleersnyder, B., Dekimpe, M. and Steenkamp, J., 2007, How Business Cycles Contribute to Private-Label Success: Evidence from the United States and Europe, Journal of Marketing, 71(1), 1-15.

Navone, M., 2012, Investors' Distraction and Strategic Re-Pricing Decision, Journal of Banking and Finance, 36(5), pp. 1291-1303.

Reuter, J. and E. Zitzewitz, 2006, Do ads influence editors? Advertising and bias in the financial media, Quarterly Journal of Economics 121(1), pp. 197-227.

Roche, C., P. Ducasse, C. Liao and C. Grevler, 2010, A New World Order of Consumption, BCG Global Report on Consumer Sentiment. 
Santos, J. and A. Winton, 2008, Bank Loans, Bonds, and Information Monopolies across the Business Cycle, Journal of Finance, 63(3), pp. 1315-1359.

Sirri, E. and P. Tufano, 1998. Costly search and mutual fund flows. Journal of Finance, 53(5), 15891622.

Wilcox, R., 2003, Bargain hunting or star gazing? Investors' preferences for stock mutual funds, Journal of Business, 76(4), pp. 645-663. 
Table 1

Variables Description

\begin{tabular}{|c|c|}
\hline Variable & Description \\
\hline Flow & $\begin{array}{l}\text { The dependent variable in this study is the quarterly net percentage investment flow. Flows } \\
\text { are calculated on a monthly bases as } \\
\qquad F l o w_{i t}=\frac{T N A_{i t}-T N A_{i t-1}\left(1+r_{i t}\right)}{T N A_{i t-1}} \\
\text { Where } T N A_{i t} \text { is the asset under management of fund } i \text { in month } t \text { and } r_{i t} \text { is the return of fund } i \\
\text { in month } t \text {. Flows are calculated monthly and aggregated at the quarterly level. Flows are } \\
\text { winsorized at the } 5 \% \text { level and normalized within the investment objective / quarter. }\end{array}$ \\
\hline Flow $_{\text {t-1 }}$ & The lagged value of Flow. \\
\hline Perf & $\begin{array}{l}\text { The quarterly after-expenses quarterly return of the fund normalized within the investment } \\
\text { objective / quarter. }\end{array}$ \\
\hline Mid & $\begin{array}{l}\text { A dummy variable equal to } 1 \text { if the fund quarterly performance is in the middle third of its } \\
\text { investment objective ranking. }\end{array}$ \\
\hline High & $\begin{array}{l}\text { A dummy variable equal to } 1 \text { if the fund quarterly performance is in the top third of its } \\
\text { investment objective ranking. }\end{array}$ \\
\hline Exp & Total expense ratio normalized within the investment objective / quarter. \\
\hline Size & (Natural log of) Asset under management of the fund at the beginning of the quarter. \\
\hline Age & (Natural log of) fund age in months. \\
\hline No Load & $\begin{array}{l}\text { Dummy variable equal to } 1 \text { if the fund share does not charge front or back-end load and has } \\
12 \text { b- } 1 \text { fees below } 1 \% \text {. }\end{array}$ \\
\hline Institutional & $\begin{array}{l}\text { Dummy variable equal to } 1 \text { if the fund share is reserved to institutional investors. Prior to } \\
1999 \text { the individuation is by name. }\end{array}$ \\
\hline St. Dev. & $\begin{array}{l}\text { Standard deviation of the fund monthly returns over the } 12 \text { months prior to the beginning of } \\
\text { the quarter. The variable is normalized within the investment objective / quarter. }\end{array}$ \\
\hline IC Size & $\begin{array}{l}\text { (Natural log of) Asset under management of funds managed by the same investment } \\
\text { company. }\end{array}$ \\
\hline IC Flow & $\begin{array}{l}\text { Asset weighted average normalized quarterly flow for all the other funds managed by the } \\
\text { same investment company. }\end{array}$ \\
\hline
\end{tabular}


Table 2

\section{Descriptive Statistics}

The table reports descriptive statistics for the sample of mutual funds considered in this paper divided by investment objective (Panel A). Panel B reports the same statistics for five representative years within the period considered in this paper.

\begin{tabular}{|c|c|c|c|c|c|c|c|}
\hline \multicolumn{8}{|c|}{ Panel A: Investment Objectives } \\
\hline & $\begin{array}{c}\text { N. of } \\
\text { Observations }\end{array}$ & $\begin{array}{c}\text { Average } \\
\text { Size } \\
(\mathrm{m} \$)\end{array}$ & $\begin{array}{c}\text { Average } \\
\text { Age } \\
\text { (Years) }\end{array}$ & $\begin{array}{c}\text { Average } \\
\text { Exp. Ratio } \\
\text { (\%) }\end{array}$ & $\begin{array}{c}\text { Average } \\
\text { Flow } \\
\text { (\%) }\end{array}$ & $\begin{array}{c}\text { Average } \\
\text { Yearly } \\
\text { Return } \\
(\%) \\
\end{array}$ & $\begin{array}{c}\text { Average } \\
\text { St. Dev. } \\
(\%)\end{array}$ \\
\hline Aggressive Growth & 17,630 & 852.9 & 13.2 & 1.48 & -0.43 & 11.2 & 19.5 \\
\hline Growth & 88,902 & 861.8 & 11.4 & 1.33 & -0.12 & 9.1 & 16.4 \\
\hline Growth \& Income & 41,689 & 1591.6 & 12.8 & 1.19 & -0.08 & 8.1 & 12.4 \\
\hline Total & 148,221 & 1066.0 & 12.0 & 1.31 & -0.15 & 9.1 & 15.6 \\
\hline \multicolumn{8}{|c|}{ Panel B: Representative Years } \\
\hline & $\begin{array}{c}\text { N. of } \\
\text { Observations }\end{array}$ & $\begin{array}{c}\text { Average } \\
\text { Size } \\
\text { (m\$) }\end{array}$ & $\begin{array}{c}\text { Average } \\
\text { Age } \\
\text { (Years) }\end{array}$ & $\begin{array}{l}\text { Average } \\
\text { Exp. Ratio } \\
\text { (\%) }\end{array}$ & $\begin{array}{c}\text { Average } \\
\text { Flow } \\
\text { (\%) }\end{array}$ & $\begin{array}{c}\text { Average } \\
\text { Yearly } \\
\text { Return } \\
(\%) \\
\end{array}$ & $\begin{array}{c}\text { Average } \\
\text { St. Dev. } \\
(\%)\end{array}$ \\
\hline 1991 & 1,611 & 526.8 & 9.7 & 1.17 & 2.34 & 13.4 & 17.8 \\
\hline 1995 & 3,148 & 857.2 & 10.1 & 1.23 & 1.55 & 14.1 & 9.5 \\
\hline 2001 & 9,970 & 967.9 & 9.4 & 1.34 & 0.92 & -11.7 & 21.7 \\
\hline 2005 & 10,534 & 1083.0 & 12.5 & 1.36 & -1.02 & 11.3 & 10.6 \\
\hline 2011 & 7,282 & 1347.0 & 17.0 & 1.21 & -1.00 & 17.6 & 16.7 \\
\hline
\end{tabular}


Table 3

Macroeconomic proxy variables during expansion and recession quarters

The table reports mean values (and standard errors in parenthesis) for the eight continuous macroeconomic proxy variables separately for the subsamples of expansion and recession quarters according to the NBER recession indicator. The third column reports the differences (with standard errors) and significance levels. ***, $* *$ and $*$ represent significance at the $1 \%, 5 \%$ and $10 \%$ respectively.

\begin{tabular}{lccc}
\hline \hline & $\begin{array}{c}\text { NBER } \\
\text { Expansion }\end{array}$ & $\begin{array}{c}\text { NBER } \\
\text { Recession }\end{array}$ & Difference \\
\hline$\Delta$ Industrial Production & 0.7530 & -1.8107 & $-2.5637^{* * *}$ \\
& $(0.071)$ & $(0.469)$ & $(0.475)$ \\
Capacity Utilization & 79.9505 & 75.3361 & $-4.6144^{* * *}$ \\
& $(0.413)$ & $(1.342)$ & $(1.405)$ \\
$\Delta$ Coincident Index & 0.7925 & -0.6750 & $-1.4675^{* * *}$ \\
& $(0.044)$ & $(0.248)$ & $(0.252)$ \\
Leading Index & 1.3215 & -0.8345 & $-2.156 * * *$ \\
& $(0.063)$ & $(0.317)$ & $(0.323)$ \\
Consumer Sentiment & & & $-0.1738^{* * *}$ \\
& 0.8957 & 0.7219 & $(0.037)$ \\
Consumer Confidence & $(0.014)$ & $(0.035)$ & \\
& & & $-0.262^{* * *}$ \\
& 0.9548 & 0.6929 & $(0.085)$ \\
NFIB Small Bus. Optimism & $(0.032)$ & $(0.079)$ & $-0.0677^{* * *}$ \\
& & & $(0.016)$ \\
& 0.9902 & 0.9225 & $(0.066)$ \\
\hline \hline
\end{tabular}


Table 4

Correlation among macroeconomic conditions proxy variables

The table reports correlation coefficients among the ten macroeconomic proxy variables used in the paper.

Correlations are calculated on the monthly time series of the variables from 1991 to 2011.

NBER Recession

$\Delta$ Industrial Production

Capacity Utilization

$\Delta$ Coincident Index

Leading Index

Consumer Sentiment

Consumer Confidence

NFIB Small Bus. Optimism

ABC WP Cons. Comfort

\begin{tabular}{|c|c|c|c|c|c|c|c|c|}
\hline 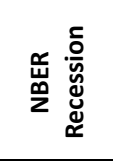 & 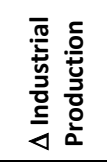 & 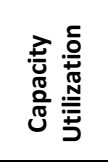 & 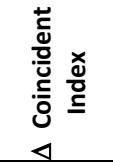 & 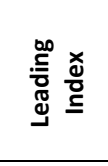 & 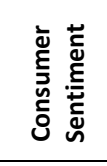 & 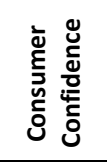 & 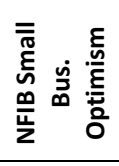 & 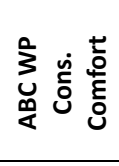 \\
\hline \multicolumn{9}{|l|}{1.000} \\
\hline $\begin{array}{c}-0.743 \\
(0.000)\end{array}$ & 1.000 & & & & & & & \\
\hline $\begin{array}{c}-0.406 \\
(0.000)\end{array}$ & $\begin{array}{l}0.424 \\
(0.000)\end{array}$ & 1.000 & & & & & & \\
\hline $\begin{array}{c}-0.742 \\
(0.000)\end{array}$ & $\begin{array}{l}0.783 \\
(0.000)\end{array}$ & $\begin{array}{l}0.727 \\
(0.000)\end{array}$ & 1.000 & & & & & \\
\hline $\begin{array}{c}-0.768 \\
(0.000)\end{array}$ & $\begin{array}{l}0.860 \\
(0.000)\end{array}$ & $\begin{array}{l}0.585 \\
(0.000)\end{array}$ & $\begin{array}{l}0.877 \\
(0.000)\end{array}$ & 1.000 & & & & \\
\hline $\begin{array}{c}-0.461 \\
(0.000)\end{array}$ & $\begin{array}{l}0.479 \\
(0.000)\end{array}$ & $\begin{array}{l}0.602 \\
(0.000)\end{array}$ & $\begin{array}{l}0.600 \\
(0.000)\end{array}$ & $\begin{array}{l}0.524 \\
(0.000)\end{array}$ & 1.000 & & & \\
\hline $\begin{array}{c}-0.324 \\
(0.003)\end{array}$ & $\begin{array}{l}0.367 \\
(0.001)\end{array}$ & $\begin{array}{l}0.591 \\
(0.000)\end{array}$ & $\begin{array}{l}0.548 \\
(0.000)\end{array}$ & $\begin{array}{l}0.366 \\
(0.001)\end{array}$ & $\begin{array}{l}0.934 \\
(0.000)\end{array}$ & 1.000 & & \\
\hline $\begin{array}{c}-0.487 \\
(0.000)\end{array}$ & $\begin{array}{l}0.457 \\
(0.000)\end{array}$ & $\begin{array}{l}0.601 \\
(0.000)\end{array}$ & $\begin{array}{l}0.600 \\
(0.000)\end{array}$ & $\begin{array}{l}0.553 \\
(0.000)\end{array}$ & $\begin{array}{l}0.821 \\
(0.000)\end{array}$ & $\begin{array}{l}0.726 \\
(0.000)\end{array}$ & 1.000 & \\
\hline $\begin{array}{c}-0.264 \\
(0.015)\end{array}$ & $\begin{array}{l}0.265 \\
(0.015)\end{array}$ & $\begin{array}{l}0.480 \\
(0.000)\end{array}$ & $\begin{array}{l}0.445 \\
(0.000)\end{array}$ & $\begin{array}{l}0.275 \\
(0.011)\end{array}$ & $\begin{array}{l}0.911 \\
(0.000)\end{array}$ & $\begin{array}{l}0.968 \\
(0.000)\end{array}$ & $\begin{array}{l}0.663 \\
(0.000)\end{array}$ & 1.000 \\
\hline
\end{tabular}




\section{Table 5}

\section{Basic Model Estimation}

The table reports the relationship between the quarterly net investment flow and the set of explanatory variables described in Table 1 on a sample of mutual fund shares from 1991 to 2011. The relationship is estimated with a multivariate OLS regression (Models 1a and 1b), a panel regression with fund fixed effects (Models 2a and 2b) and a Fama and McBeth repeated cross-section (Models 3a and 3b). T-statistics in parentheses. ***, ** and * represent significance at the $1 \%, 5 \%$ and $10 \%$ respectively.

\begin{tabular}{|c|c|c|c|c|c|c|}
\hline & \multicolumn{2}{|c|}{ OLS } & \multicolumn{2}{|c|}{ Panel FE } & \multicolumn{2}{|c|}{ Fama-McBeth } \\
\hline & (1a) & (1b) & (2a) & (2b) & (3a) & (3b) \\
\hline Constant & $\begin{array}{c}0.906 * * * \\
(15.398)\end{array}$ & $\begin{array}{c}0.311^{* * *} \\
(10.493)\end{array}$ & $\begin{array}{c}2.222^{* * *} \\
(20.015)\end{array}$ & $\begin{array}{c}1.298 * * * \\
(18.718)\end{array}$ & $\begin{array}{c}1.019 * * * \\
(20.582)\end{array}$ & $\begin{array}{c}0.439 * * * \\
(4.503)\end{array}$ \\
\hline Flow $_{t-1}$ & & $\begin{array}{c}0.532 * * * \\
(89.232)\end{array}$ & & $\begin{array}{c}0.438 * * * \\
(70.183)\end{array}$ & & $\begin{array}{c}0.504^{* * *} \\
(73.295)\end{array}$ \\
\hline Perf & $\begin{array}{c}0.199 * * * \\
(20.644)\end{array}$ & $\begin{array}{c}0.067^{* * *} \\
(11.223)\end{array}$ & $\begin{array}{c}0.195^{* * *} \\
(21.351)\end{array}$ & $\begin{array}{c}0.087^{* * *} \\
(14.030)\end{array}$ & $\begin{array}{c}0.260 * * * \\
(18.092)\end{array}$ & $\begin{array}{c}0.102 * * * \\
(7.551)\end{array}$ \\
\hline Med & $\begin{array}{c}0.094 * * * \\
(8.664)\end{array}$ & $\begin{array}{c}0.076^{* * *} \\
(11.071)\end{array}$ & $\begin{array}{c}0.079 * * * \\
(8.195)\end{array}$ & $\begin{array}{c}0.072 * * * \\
(10.299)\end{array}$ & $\begin{array}{c}0.070^{* * *} \\
(4.471)\end{array}$ & $\begin{array}{c}0.083^{* * *} \\
(5.275)\end{array}$ \\
\hline High & $\begin{array}{c}0.229 * * * \\
(11.890)\end{array}$ & $\begin{array}{l}0.161^{* * *} \\
(12.911)\end{array}$ & $\begin{array}{c}0.186^{* * *} \\
(10.523)\end{array}$ & $\begin{array}{c}0.146 * * * \\
(11.536)\end{array}$ & $\begin{array}{c}0.195^{* * *} \\
(7.763)\end{array}$ & $\begin{array}{c}0.157^{* * *} \\
(7.289)\end{array}$ \\
\hline Exp & $\begin{array}{c}-0.099 * * * \\
(-13.673)\end{array}$ & $\begin{array}{c}-0.067^{* * *} \\
(-19.068)\end{array}$ & $\begin{array}{c}-0.061^{* * *} \\
(-2.822)\end{array}$ & $\begin{array}{c}-0.080 * * * \\
(-5.875)\end{array}$ & $\begin{array}{c}-0.081 * * * \\
(-8.433)\end{array}$ & $\begin{array}{c}-0.060 * * * \\
(-7.575)\end{array}$ \\
\hline Size & $\begin{array}{c}-0.020^{* * *} \\
(-5.039)\end{array}$ & $\begin{array}{c}-0.026^{* * *} \\
(-13.225)\end{array}$ & $\begin{array}{c}-0.100^{* * *} \\
(-10.494)\end{array}$ & $\begin{array}{c}-0.133^{* * *} \\
(-20.901)\end{array}$ & $\begin{array}{c}-0.018^{* * *} \\
(-4.140)\end{array}$ & $\begin{array}{c}-0.022^{* * *} \\
(-3.691)\end{array}$ \\
\hline Age & $\begin{array}{c}-0.261^{* * *} \\
(-23.415)\end{array}$ & $\begin{array}{c}-0.088^{* * *} \\
(-15.841)\end{array}$ & $\begin{array}{c}-0.559 * * * \\
(-29.356)\end{array}$ & $\begin{array}{c}-0.287^{* * *} \\
(-23.796)\end{array}$ & $\begin{array}{c}-0.277^{* * *} \\
(-24.972)\end{array}$ & $\begin{array}{c}-0.124 * * * \\
(-4.378)\end{array}$ \\
\hline No Load & $\begin{array}{l}0.026^{*} \\
(1.792)\end{array}$ & $\begin{array}{c}0.008 \\
(1.158)\end{array}$ & $\begin{array}{c}0.013 \\
(0.564)\end{array}$ & $\begin{array}{c}0.011 \\
(0.873)\end{array}$ & $\begin{array}{c}0.017^{* * *} \\
(2.919)\end{array}$ & $\begin{array}{c}0.004 \\
(0.908)\end{array}$ \\
\hline Institutional & $\begin{array}{c}0.077^{* * *} \\
(4.193)\end{array}$ & $\begin{array}{c}0.009 \\
(1.026)\end{array}$ & $\begin{array}{c}0.133^{* * *} \\
(3.364)\end{array}$ & $\begin{array}{c}0.053^{* *} \\
(2.213)\end{array}$ & $\begin{array}{c}0.004 \\
(0.150)\end{array}$ & $\begin{array}{c}-0.004 \\
(-0.159)\end{array}$ \\
\hline St. Dev. & $\begin{array}{c}-0.037^{* * *} \\
(-6.833)\end{array}$ & $\begin{array}{c}-0.019 * * * \\
(-7.148)\end{array}$ & $\begin{array}{c}0.000 \\
(0.022)\end{array}$ & $\begin{array}{c}-0.001 \\
(-0.180)\end{array}$ & $\begin{array}{c}-0.033^{* * *} \\
(-3.114)\end{array}$ & $\begin{array}{c}-0.018^{* *} \\
(-2.235)\end{array}$ \\
\hline IC Size & $\begin{array}{c}0.046 * * * \\
(15.390)\end{array}$ & $\begin{array}{c}0.022^{* * *} \\
(15.341)\end{array}$ & $\begin{array}{c}0.106 * * * \\
(9.044)\end{array}$ & $\begin{array}{c}0.083^{* * *} \\
(11.329)\end{array}$ & $\begin{array}{c}0.042^{* * *} \\
(13.273)\end{array}$ & $\begin{array}{c}0.024^{* * *} \\
(9.839)\end{array}$ \\
\hline IC Flow & $\begin{array}{c}0.508^{* * *} \\
(26.655)\end{array}$ & $\begin{array}{c}0.294^{* * *} \\
(25.573)\end{array}$ & $\begin{array}{c}0.426 * * * \\
(23.430)\end{array}$ & $\begin{array}{c}0.301^{* * *} \\
(23.071)\end{array}$ & $\begin{array}{c}0.437^{* * *} \\
(18.918)\end{array}$ & $\begin{array}{c}0.225^{* * *} \\
(5.855)\end{array}$ \\
\hline $\mathrm{N}$ & 148221 & 143506 & 148221 & 143506 & 148221 & 143506 \\
\hline $\operatorname{adj.~R-sq~}$ & 0.159 & 0.405 & 0.154 & 0.316 & 0.207 & 0.425 \\
\hline
\end{tabular}


Table 6

Investment Flows in Good and Tough Times

The table reports the results of a t-test on the difference between net investment flows during good and tough times into funds ranked in quintiles according to past performance, volatility and expense ratio. Good and Tough times are defined as the top and bottom thirds of the time series distribution of changes in the US Coincident Index (Panel A) and of the Consumer Confidence Index (Panel B).

\begin{tabular}{|c|c|c|c|c|c|c|c|c|c|c|c|}
\hline \multicolumn{12}{|c|}{ Panel A: $\Delta$ Coincident Index } \\
\hline & \multicolumn{3}{|c|}{ Performance } & \multicolumn{4}{|c|}{ Risk } & & \multicolumn{3}{|c|}{ Expense Ratio } \\
\hline & Good Times & Tough Times & Difference & & Good Times & Tough Times & Difference & & Good Times & Tough Times & Difference \\
\hline Q1 (Low) & $\begin{array}{l}-0.5514 \\
(0.011)\end{array}$ & $\begin{array}{l}-0.3695 \\
(0.010)\end{array}$ & $\begin{array}{c}0.1819^{* * *} \\
(0.015)\end{array}$ & Q1 (Low) & $\begin{array}{l}-0.0530 \\
(0.013)\end{array}$ & $\begin{array}{l}0.1668 \\
(0.013)\end{array}$ & $\begin{array}{c}0.2198^{* * *} \\
(0.018)\end{array}$ & Q1 (Cheap) & $\begin{array}{l}0.0403 \\
(0.011)\end{array}$ & $\begin{array}{l}0.0907 \\
(0.011)\end{array}$ & $\begin{array}{c}0.0504^{* * *} \\
(0.016)\end{array}$ \\
\hline Q2 & $\begin{array}{l}-0.2492 \\
(0.010)\end{array}$ & $\begin{array}{l}-0.2008 \\
(0.008)\end{array}$ & $\begin{array}{c}0.0485^{* * *} \\
(0.013)\end{array}$ & Q2 & $\begin{array}{l}-0.0592 \\
(0.010)\end{array}$ & $\begin{array}{l}0.0373 \\
(0.010)\end{array}$ & $\begin{array}{c}0.0966^{* * *} \\
(0.014)\end{array}$ & Q2 & $\begin{array}{l}-0.0202 \\
(0.010)\end{array}$ & $\begin{array}{l}0.0468 \\
(0.010)\end{array}$ & $\begin{array}{c}0.0669^{* * *} \\
(0.014)\end{array}$ \\
\hline Q3 & $\begin{array}{l}-0.0299 \\
(0.010)\end{array}$ & $\begin{array}{r}-0.0250 \\
(0.009)\end{array}$ & $\begin{array}{l}0.0049 \\
(0.014)\end{array}$ & Q3 & $\begin{array}{l}0.0005 \\
(0.011)\end{array}$ & $\begin{array}{r}-0.0450 \\
(0.010)\end{array}$ & $\begin{array}{c}-0.0455^{* * *} \\
(0.015)\end{array}$ & Q3 & $\begin{array}{l}-0.0236 \\
(0.012)\end{array}$ & $\begin{array}{l}0.0669 \\
(0.012)\end{array}$ & $\begin{array}{c}0.0905^{* * *} \\
(0.017)\end{array}$ \\
\hline Q4 & $\begin{array}{l}0.1708 \\
(0.011)\end{array}$ & $\begin{array}{l}0.1951 \\
(0.012)\end{array}$ & $\begin{array}{l}0.0243 \\
(0.016)\end{array}$ & Q4 & $\begin{array}{l}0.0264 \\
(0.013)\end{array}$ & $\begin{array}{l}-0.0811 \\
(0.011)\end{array}$ & $\begin{array}{c}-0.1076^{* * *} \\
(0.017)\end{array}$ & Q4 & $\begin{array}{l}0.0241 \\
(0.017)\end{array}$ & $\begin{array}{l}0.0408 \\
(0.015)\end{array}$ & $\begin{array}{l}0.0167 \\
(0.022)\end{array}$ \\
\hline Q5 (High) & $\begin{array}{l}0.5581 \\
(0.014) \\
\end{array}$ & $\begin{array}{l}0.4953 \\
(0.015) \\
\end{array}$ & $\begin{array}{c}-0.0627^{* * *} \\
(0.020) \\
\end{array}$ & Q5 (High) & $\begin{array}{l}0.1012 \\
(0.015) \\
\end{array}$ & $\begin{array}{l}-0.1078 \\
(0.012) \\
\end{array}$ & $\begin{array}{c}-0.209 * * * \\
(0.020) \\
\end{array}$ & Q5 (Expensive) & $\begin{array}{l}-0.0214 \\
(0.012) \\
\end{array}$ & $\begin{array}{l}-0.2191 \\
(0.010) \\
\end{array}$ & $\begin{array}{c}-0.1978^{* * *} \\
(0.016) \\
\end{array}$ \\
\hline Q5 - Q1 & $\begin{array}{l}1.1095 \\
(0.018) \\
\end{array}$ & $\begin{array}{l}0.8649 \\
(0.018) \\
\end{array}$ & $\begin{array}{c}-0.2446 * * * \\
(0.036) \\
\end{array}$ & Q5 - Q1 & $\begin{array}{l}0.1542 \\
(0.020) \\
\end{array}$ & $\begin{array}{l}-0.2218 \\
(0.023) \\
\end{array}$ & $\begin{array}{c}-0.376^{* * *} \\
(0.043) \\
\end{array}$ & Q5 - Q1 & $\begin{array}{r}-0.0616 \\
(0.017) \\
\end{array}$ & $\begin{array}{c}-0.3098 \\
(0.015) \\
\end{array}$ & $\begin{array}{c}-0.2481^{* * *} \\
(0.031) \\
\end{array}$ \\
\hline \multicolumn{12}{|c|}{ Panel B: Consumer Confidence Index } \\
\hline & \multicolumn{3}{|c|}{ Performance } & \multicolumn{4}{|c|}{ Risk } & & \multicolumn{3}{|c|}{ Expense Ratio } \\
\hline & Good Times & Tough Times & Difference & & Good Times & Tough Times & Difference & & Good Times & Tough Times & Difference \\
\hline Q1 (Low) & $\begin{array}{l}-0.5735 \\
(0.010)\end{array}$ & $\begin{array}{l}-0.3074 \\
(0.011)\end{array}$ & $\begin{array}{c}0.2661^{* * *} \\
(0.015)\end{array}$ & Q1 (Low) & $\begin{array}{r}-0.0370 \\
(0.012)\end{array}$ & $\begin{array}{l}0.0508 \\
(0.013)\end{array}$ & $\begin{array}{c}0.0879 * * * \\
(0.018)\end{array}$ & Q1 (Cheap) & $\begin{array}{l}0.0045 \\
(0.010)\end{array}$ & $\begin{array}{l}0.2276 \\
(0.012)\end{array}$ & $\begin{array}{c}0.2232^{* * *} \\
(0.016)\end{array}$ \\
\hline Q2 & $\begin{array}{l}-0.2532 \\
(0.010)\end{array}$ & $\begin{array}{l}-0.1362 \\
(0.010)\end{array}$ & $\begin{array}{c}0.1169 * * * \\
(0.013)\end{array}$ & Q2 & $\begin{array}{l}-0.0454 \\
(0.009)\end{array}$ & $\begin{array}{l}0.0202 \\
(0.011)\end{array}$ & $\begin{array}{c}0.0656^{* * *} \\
(0.014)\end{array}$ & Q2 & $\begin{array}{l}-0.0473 \\
(0.009)\end{array}$ & $\begin{array}{l}0.1264 \\
(0.011)\end{array}$ & $\begin{array}{c}0.1737^{* * *} \\
(0.014)\end{array}$ \\
\hline Q3 & $\begin{array}{l}-0.0501 \\
(0.010)\end{array}$ & $\begin{array}{l}0.0040 \\
(0.010)\end{array}$ & $\begin{array}{c}0.054^{* * *} \\
(0.014)\end{array}$ & Q3 & $\begin{array}{l}-0.0064 \\
(0.010)\end{array}$ & $\begin{array}{l}-0.0240 \\
(0.011)\end{array}$ & $\begin{array}{r}-0.0176 \\
(0.015)\end{array}$ & Q3 & $\begin{array}{l}-0.0514 \\
(0.012)\end{array}$ & $\begin{array}{l}0.0382 \\
(0.011)\end{array}$ & $\begin{array}{c}0.0895^{* * *} \\
(0.016)\end{array}$ \\
\hline Q4 & $\begin{array}{l}0.1712 \\
(0.010)\end{array}$ & $\begin{array}{l}0.1410 \\
(0.012)\end{array}$ & $\begin{array}{c}-0.0302^{*} \\
(0.016)\end{array}$ & Q4 & $\begin{array}{l}0.0260 \\
(0.012)\end{array}$ & $\begin{array}{l}-0.0233 \\
(0.012)\end{array}$ & $\begin{array}{c}-0.0494^{* * *} \\
(0.017)\end{array}$ & Q4 & $\begin{array}{l}0.0375 \\
(0.016)\end{array}$ & $\begin{array}{l}0.0102 \\
(0.014)\end{array}$ & $\begin{array}{r}-0.0272 \\
(0.021)\end{array}$ \\
\hline Q5 (High) & $\begin{array}{l}0.5645 \\
(0.012) \\
\end{array}$ & $\begin{array}{l}0.3379 \\
(0.015) \\
\end{array}$ & $\begin{array}{c}-0.2266^{* * *} \\
(0.020) \\
\end{array}$ & Q5 (High) & $\begin{array}{l}0.0632 \\
(0.014) \\
\end{array}$ & $\begin{array}{l}-0.0311 \\
(0.014) \\
\end{array}$ & $\begin{array}{c}-0.0943^{* * *} \\
(0.020) \\
\end{array}$ & Q5 (Expensive) & $\begin{array}{l}0.0462 \\
(0.011) \\
\end{array}$ & $\begin{array}{c}-0.3892 \\
(0.010) \\
\end{array}$ & $\begin{array}{c}-0.4355^{* * *} \\
(0.015) \\
\end{array}$ \\
\hline Q5 - Q1 & $\begin{array}{l}1.1380 \\
(0.016)\end{array}$ & $\begin{array}{l}0.6453 \\
(0.019)\end{array}$ & $\begin{array}{c}-0.4926 * * * \\
(0.035)\end{array}$ & Q5 - Q1 & $\begin{array}{l}0.1002 \\
(0.019)\end{array}$ & $\begin{array}{l}-0.2218 \\
(0.023)\end{array}$ & $\begin{array}{c}-0.322^{* * *} \\
(0.041)\end{array}$ & Q5 - Q1 & $\begin{array}{l}0.0418 \\
(0.015)\end{array}$ & $\begin{array}{l}-0.6169 \\
(0.016)\end{array}$ & $\begin{array}{c}-0.6586^{* * *} \\
(0.031)\end{array}$ \\
\hline
\end{tabular}


Table 7

\section{Investors' reaction to macroeconomic conditions}

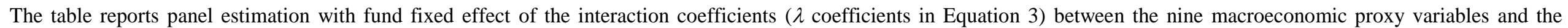
explanatory variables described in Table 1 . T-statistics in parentheses. $* * * * *$ and $*$ represent significance at the $1 \%, 5 \%$ and $10 \%$ respectively.

\begin{tabular}{|c|c|c|c|c|c|c|c|c|c|}
\hline & (1) & (2) & (3) & (4) & (5) & (6) & (7) & (8) & (9) \\
\hline & $\begin{array}{c}\text { NBER } \\
\text { Recession }\end{array}$ & $\begin{array}{c}\Delta \\
\text { Industrial } \\
\text { Production }\end{array}$ & $\begin{array}{l}\text { Capacity } \\
\text { Utilization }\end{array}$ & $\begin{array}{c}\Delta \\
\text { Coincident } \\
\text { Index }\end{array}$ & $\begin{array}{l}\text { Leading } \\
\text { Index }\end{array}$ & $\begin{array}{l}\text { Consumer } \\
\text { Sentiment }\end{array}$ & $\begin{array}{l}\text { Consumer } \\
\text { Confidence }\end{array}$ & $\begin{array}{l}\text { NFIB Small } \\
\text { Bus. } \\
\text { Optimism }\end{array}$ & $\begin{array}{l}\text { ABC WP } \\
\text { Cons. } \\
\text { Comfort }\end{array}$ \\
\hline \multirow[t]{2}{*}{ Constant } & 0.035 & -0.003 & $0.053^{* * *}$ & 0.070 & 0.016 & $1.167 * * *$ & $0.566^{* * *}$ & $2.163^{*}$ & $0.735 * * *$ \\
\hline & $(0.377)$ & $(-0.093)$ & (3.897) & (1.156) & $(0.370)$ & (2.749) & $(2.844)$ & $(1.771)$ & (3.037) \\
\hline Perf & $\begin{array}{c}-0.054^{* * *} \\
(-3.094)\end{array}$ & $\begin{array}{c}-0.035^{* * *} \\
(-7.974)\end{array}$ & $\begin{array}{c}-0.011 * * * \\
(-6.491)\end{array}$ & $\begin{array}{c}-0.050 * * * \\
(-5.632)\end{array}$ & $\begin{array}{c}-0.046 * * * \\
(-7.404)\end{array}$ & $\begin{array}{c}-0.434^{* * *} \\
(-8.659)\end{array}$ & $\begin{array}{c}-0.193 * * * \\
(-8.186)\end{array}$ & $\begin{array}{c}-0.697^{* * *} \\
(-5.103)\end{array}$ & $\begin{array}{c}-0.226 * * * \\
(-7.845)\end{array}$ \\
\hline Mid & $\begin{array}{c}-0.003 \\
(-0.142)\end{array}$ & $\begin{array}{l}0.010^{*} \\
(1.751)\end{array}$ & $\begin{array}{c}-0.009 * * * \\
(-3.717)\end{array}$ & $\begin{array}{c}-0.008 \\
(-0.686)\end{array}$ & $\begin{array}{c}0.008 \\
(1.028)\end{array}$ & $\begin{array}{c}-0.105 \\
(-1.632)\end{array}$ & $\begin{array}{c}-0.092^{* * *} \\
(-2.990)\end{array}$ & $\begin{array}{l}-0.277^{*} \\
(-1.700)\end{array}$ & $\begin{array}{c}-0.104 * * * \\
(-2.802)\end{array}$ \\
\hline High & $\begin{array}{c}0.025 \\
(0.638)\end{array}$ & $\begin{array}{c}0.023^{* *} \\
(2.290)\end{array}$ & $\begin{array}{c}-0.014 * * * \\
(-3.732)\end{array}$ & $\begin{array}{c}-0.008 \\
(-0.397)\end{array}$ & $\begin{array}{c}0.015 \\
(1.049)\end{array}$ & $\begin{array}{c}-0.210 * * \\
(-1.967)\end{array}$ & $\begin{array}{c}-0.160 * * * \\
(-3.145)\end{array}$ & $\begin{array}{c}-0.685^{* *} \\
(-2.377)\end{array}$ & $\begin{array}{c}-0.173 * * * \\
(-2.824)\end{array}$ \\
\hline Exp & $\begin{array}{c}-0.086 * * * \\
(-7.898)\end{array}$ & $\begin{array}{c}-0.029 * * * \\
(-9.519)\end{array}$ & $\begin{array}{c}-0.021 * * * \\
(-13.552)\end{array}$ & $\begin{array}{c}-0.062 * * * \\
(-9.644)\end{array}$ & $\begin{array}{c}-0.055^{* * *} \\
(-11.605)\end{array}$ & $\begin{array}{c}-0.859 * * * \\
(-16.275)\end{array}$ & $\begin{array}{c}-0.350 * * * \\
(-14.072)\end{array}$ & $\begin{array}{c}-1.664 * * * \\
(-12.487)\end{array}$ & $\begin{array}{c}-0.442 * * * \\
(-13.938)\end{array}$ \\
\hline Size & $\begin{array}{c}-0.015^{* *} \\
(-2.225)\end{array}$ & $\begin{array}{c}-0.006 * * * \\
(-3.247)\end{array}$ & $\begin{array}{c}-0.004^{* * *} \\
(-4.058)\end{array}$ & $\begin{array}{c}-0.010 * * \\
(-2.463)\end{array}$ & $\begin{array}{c}-0.011 * * * \\
(-3.812)\end{array}$ & $\begin{array}{c}-0.146 * * * \\
(-4.838)\end{array}$ & $\begin{array}{c}-0.053 * * * \\
(-3.671)\end{array}$ & $\begin{array}{c}-0.327^{* * *} \\
(-4.236)\end{array}$ & $\begin{array}{c}-0.063 * * * \\
(-3.497)\end{array}$ \\
\hline Age & $\begin{array}{c}0.040 * * \\
(2.292)\end{array}$ & $\begin{array}{c}0.014 * * * \\
(2.578)\end{array}$ & $\begin{array}{c}0.006^{* *} \\
(2.550)\end{array}$ & $\begin{array}{c}0.027^{* *} \\
(2.400)\end{array}$ & $\begin{array}{c}0.026 * * * \\
(3.272)\end{array}$ & $\begin{array}{c}0.276 * * * \\
(3.635)\end{array}$ & $\begin{array}{c}0.103 * * * \\
(2.846)\end{array}$ & $\begin{array}{c}0.745^{* * *} \\
(3.390)\end{array}$ & $\begin{array}{c}0.102^{* *} \\
(2.324)\end{array}$ \\
\hline No Load & $\begin{array}{c}-0.060 * * \\
(-2.504)\end{array}$ & $\begin{array}{c}-0.019 * * * \\
(-2.951)\end{array}$ & $\begin{array}{c}-0.013 * * * \\
(-4.092)\end{array}$ & $\begin{array}{c}-0.028 * * \\
(-2.039)\end{array}$ & $\begin{array}{c}-0.026 * * * \\
(-2.596)\end{array}$ & $\begin{array}{c}-0.160 \\
(-1.564)\end{array}$ & $\begin{array}{c}-0.039 \\
(-0.829)\end{array}$ & $\begin{array}{l}-0.557^{*} \\
(-1.952)\end{array}$ & $\begin{array}{c}-0.013 \\
(-0.227)\end{array}$ \\
\hline Institutional & $\begin{array}{c}-0.002 \\
(-0.081)\end{array}$ & $\begin{array}{c}-0.004 \\
(-0.536)\end{array}$ & $\begin{array}{c}-0.008^{* *} \\
(-2.065)\end{array}$ & $\begin{array}{c}-0.013 \\
(-0.783)\end{array}$ & $\begin{array}{c}-0.007 \\
(-0.604)\end{array}$ & $\begin{array}{c}-0.139 \\
(-1.067)\end{array}$ & $\begin{array}{c}-0.042 \\
(-0.695)\end{array}$ & $\begin{array}{c}-0.320 \\
(-0.939)\end{array}$ & $\begin{array}{c}-0.022 \\
(-0.289)\end{array}$ \\
\hline St. Dev. & $\begin{array}{c}0.109 * * * \\
(11.982)\end{array}$ & $\begin{array}{c}0.022 * * * \\
(8.986)\end{array}$ & $\begin{array}{c}0.004 * * * \\
(3.318)\end{array}$ & $\begin{array}{c}0.058 * * * \\
(10.309)\end{array}$ & $\begin{array}{c}0.033^{* * *} \\
(8.919)\end{array}$ & $\begin{array}{c}0.211^{* * *} \\
(6.035)\end{array}$ & $\begin{array}{c}0.086 * * * \\
(5.033)\end{array}$ & $\begin{array}{c}0.758^{* * *} \\
(8.100)\end{array}$ & $\begin{array}{c}0.083^{* * *} \\
(3.966)\end{array}$ \\
\hline IC Size & $\begin{array}{c}-0.015 * * * \\
(-3.184)\end{array}$ & $\begin{array}{c}-0.003 * * \\
(-2.495)\end{array}$ & $\begin{array}{c}-0.005^{* * *} \\
(-7.411)\end{array}$ & $\begin{array}{c}-0.014 * * * \\
(-5.070)\end{array}$ & $\begin{array}{c}-0.008 * * * \\
(-4.027)\end{array}$ & $\begin{array}{c}-0.168^{* * *} \\
(-7.886)\end{array}$ & $\begin{array}{c}-0.073 * * * \\
(-7.373)\end{array}$ & $\begin{array}{c}-0.407^{* * *} \\
(-7.531)\end{array}$ & $\begin{array}{c}-0.087^{* * *} \\
(-6.909)\end{array}$ \\
\hline IC Flow & $\begin{array}{c}-0.028 \\
(-0.913) \\
\end{array}$ & $\begin{array}{c}0.002 \\
(0.245) \\
\end{array}$ & $\begin{array}{c}0.006^{*} \\
(1.847) \\
\end{array}$ & $\begin{array}{c}-0.011 \\
(-0.648) \\
\end{array}$ & $\begin{array}{c}0.002 \\
(0.130) \\
\end{array}$ & $\begin{array}{c}-0.200 * * \\
(-2.001) \\
\end{array}$ & $\begin{array}{l}-0.086^{*} \\
(-1.759) \\
\end{array}$ & $\begin{array}{c}-0.888^{* * *} \\
(-3.340)\end{array}$ & $\begin{array}{c}-0.117^{* *} \\
(-1.986) \\
\end{array}$ \\
\hline $\mathrm{N}$ & 148221 & 148221 & 148221 & 148221 & 148221 & 148221 & 148221 & 148221 & 148221 \\
\hline adj. R-sq & 0.158 & 0.158 & 0.165 & 0.161 & 0.161 & 0.172 & 0.170 & 0.165 & 0.171 \\
\hline
\end{tabular}


Table 8

Present Conditions and Future Expectations

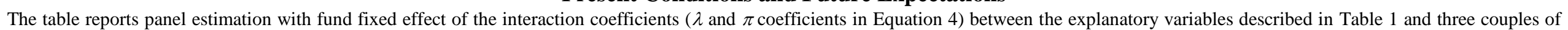

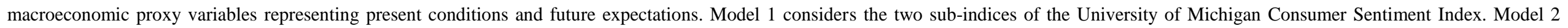

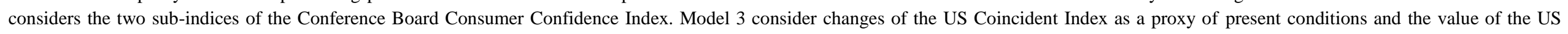
Leading Index as a proxy for future expectations. T-statistics in parentheses. ***, ** and * represent significance at the $1 \%, 5 \%$ and $10 \%$ respectively.

(1)

(2)

(3)

\begin{tabular}{|c|c|c|c|c|c|c|}
\hline & \multicolumn{2}{|c|}{ Consumer Sentiment Index } & \multicolumn{2}{|c|}{ Consumer Confidence Index } & \multirow[b]{2}{*}{$\begin{array}{c}\Delta \text { Coincident } \\
\text { Index }\end{array}$} & \multirow[b]{2}{*}{$\begin{array}{l}\text { Leading } \\
\text { Index }\end{array}$} \\
\hline & $\begin{array}{c}\text { Present } \\
\text { Conditions }\end{array}$ & $\begin{array}{c}\text { Future } \\
\text { Expectations }\end{array}$ & $\begin{array}{c}\text { Present } \\
\text { Conditions }\end{array}$ & $\begin{array}{c}\text { Future } \\
\text { Expectations }\end{array}$ & & \\
\hline \multirow[t]{2}{*}{ Constant } & $1.153^{*}$ & -0.090 & $0.295^{* *}$ & 0.120 & $0.243 * *$ & $-0.143^{*}$ \\
\hline & $(1.767)$ & $(-0.147)$ & $(2.297)$ & $(0.415)$ & $(2.275)$ & $(-1.866)$ \\
\hline \multirow[t]{2}{*}{ Perf } & 0.031 & $-0.452 * * *$ & -0.020 & $-0.277^{* * *}$ & 0.016 & $-0.053 * * *$ \\
\hline & $(0.310)$ & $(-4.305)$ & $(-1.073)$ & $(-5.555)$ & $(0.795)$ & $(-3.846)$ \\
\hline \multirow[t]{2}{*}{ Mid } & $-0.528 * * *$ & $0.429 * * *$ & $-0.108 * * *$ & $0.175^{* * *}$ & $-0.083 * * *$ & $0.060 * * *$ \\
\hline & $(-4.272)$ & (3.349) & $(-4.636)$ & $(2.837)$ & $(-3.413)$ & $(3.518)$ \\
\hline \multirow[t]{2}{*}{ High } & $-0.920 * * *$ & $0.705^{* * *}$ & $-0.187 * * *$ & $0.291 * * *$ & $-0.118^{* * *}$ & $0.089 * * *$ \\
\hline & $(-4.264)$ & (3.159) & $(-4.650)$ & $(2.676)$ & $(-2.792)$ & $(2.924)$ \\
\hline \multirow[t]{2}{*}{ Exp } & -0.030 & $-0.822 * * *$ & $-0.081 * * *$ & $-0.395 * * *$ & $0.023^{* *}$ & $-0.069 * * *$ \\
\hline & $(-0.420)$ & $(-10.779)$ & $(-5.186)$ & $(-11.144)$ & $(1.973)$ & $(-7.898)$ \\
\hline \multirow[t]{2}{*}{ Size } & $-0.085^{*}$ & -0.061 & -0.011 & $-0.065 * * *$ & $0.014 *$ & $-0.020 * * *$ \\
\hline & $(-1.939)$ & $(-1.363)$ & $(-1.164)$ & $(-3.060)$ & (1.939) & $(-3.792)$ \\
\hline \multirow[t]{2}{*}{ Age } & 0.102 & 0.187 & 0.019 & $0.132 * *$ & -0.022 & $0.041^{* * *}$ \\
\hline & $(0.840)$ & (1.612) & $(0.804)$ & $(2.480)$ & $(-1.118)$ & $(2.888)$ \\
\hline \multirow[t]{2}{*}{ No Load } & -0.229 & 0.092 & 0.033 & $-0.169 * *$ & 0.021 & $-0.040 * *$ \\
\hline & $(-1.459)$ & $(0.588)$ & (1.097) & $(-2.236)$ & $(0.860)$ & $(-2.218)$ \\
\hline \multirow[t]{2}{*}{ Institutional } & -0.214 & 0.112 & -0.014 & -0.047 & -0.018 & 0.006 \\
\hline & $(-1.178)$ & $(0.596)$ & $(-0.367)$ & $(-0.516)$ & $(-0.638)$ & $(0.305)$ \\
\hline \multirow[t]{2}{*}{ St. Dev. } & $0.263^{* * *}$ & -0.059 & $-0.034 * * *$ & $0.265^{* * *}$ & $0.075^{* * *}$ & $-0.013^{*}$ \\
\hline & $(4.496)$ & $(-1.011)$ & $(-2.948)$ & (9.810) & (7.033) & $(-1.871)$ \\
\hline \multirow[t]{2}{*}{ IC Size } & $-0.072 * *$ & $-0.093 * * *$ & $-0.027 * * *$ & $-0.054 * * *$ & $-0.018^{* * *}$ & 0.003 \\
\hline & $(-2.557)$ & $(-3.170)$ & $(-4.372)$ & $(-3.710)$ & $(-3.720)$ & (0.959) \\
\hline \multirow[t]{2}{*}{ IC Flow } & 0.196 & $-0.365^{* *}$ & -0.015 & -0.115 & -0.037 & 0.025 \\
\hline & (1.107) & $(-2.084)$ & $(-0.411)$ & $(-1.296)$ & $(-1.178)$ & $(1.079)$ \\
\hline$N$ & \multicolumn{2}{|c|}{148221} & \multicolumn{2}{|c|}{148221} & \multicolumn{2}{|c|}{148221} \\
\hline adj. R-sq & \multicolumn{2}{|c|}{0.173} & \multicolumn{2}{|c|}{0.171} & \multicolumn{2}{|c|}{0.162} \\
\hline
\end{tabular}


Table 9

\section{Alternative Explanations}

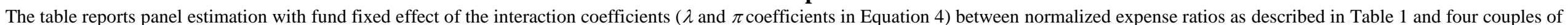

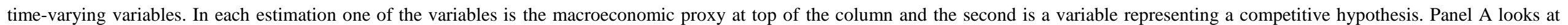

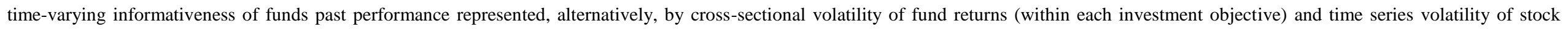

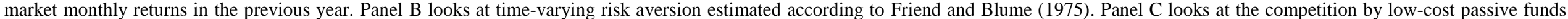

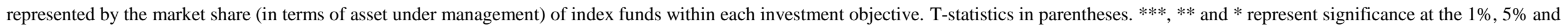
$10 \%$ respectively.

\begin{tabular}{|c|c|c|c|c|c|c|c|c|c|}
\hline & $\begin{array}{c}\text { (1) } \\
\text { NBER } \\
\text { Recession }\end{array}$ & $\begin{array}{c}\text { (2) } \\
\Delta \text { Industrial } \\
\text { Production }\end{array}$ & $\begin{array}{c}\text { (3) } \\
\text { Capacity } \\
\text { Utilization }\end{array}$ & $\begin{array}{c}(4) \\
\Delta \\
\text { Coincident } \\
\text { Index }\end{array}$ & $\begin{array}{l}\text { (5) } \\
\text { Leading } \\
\text { Index }\end{array}$ & $\begin{array}{c}\text { (6) } \\
\text { Consumer } \\
\text { Sentiment }\end{array}$ & $\begin{array}{c}\text { (7) } \\
\text { Consumer } \\
\text { Confidence }\end{array}$ & $\begin{array}{c}\text { (8) } \\
\text { NFIB Small } \\
\text { Bus. } \\
\text { Optimism }\end{array}$ & $\begin{array}{c}\text { (9) } \\
\text { ABC WP } \\
\text { Cons. } \\
\text { Comfort }\end{array}$ \\
\hline \multicolumn{10}{|c|}{ Panel A: Information Content of Funds past performance } \\
\hline Cross-sectional Volatility & $\begin{array}{l}-0.122 * * * \\
(-10.769)\end{array}$ & $\begin{array}{l}1.771 * * * \\
(12.934)\end{array}$ & $\begin{array}{l}1.615^{* * *} \\
(11.938)\end{array}$ & $\begin{array}{l}1.723^{* * *} \\
(12.613)\end{array}$ & $\begin{array}{l}1.806^{* * *} \\
(13.181)\end{array}$ & $\begin{array}{l}0.891 * * * \\
(6.662)\end{array}$ & $\begin{array}{l}0.985^{* * *} \\
(7.144)\end{array}$ & $\begin{array}{l}1.486 * * * \\
(11.112)\end{array}$ & $\begin{array}{l}0.752 * * * \\
(5.371)\end{array}$ \\
\hline Macro Proxy & $\begin{array}{l}1.914 * * * \\
(13.596)\end{array}$ & $\begin{array}{l}-0.030 * * * \\
(-10.066)\end{array}$ & $\begin{array}{l}-0.020 * * * \\
(-12.490)\end{array}$ & $\begin{array}{l}-0.058 * * * \\
(-9.176)\end{array}$ & $\begin{array}{l}-0.059 * * * \\
(-12.202)\end{array}$ & $\begin{array}{l}-0.720 * * * \\
(-13.632)\end{array}$ & $\begin{array}{l}-0.269 * * * \\
(-10.575)\end{array}$ & $\begin{array}{l}-1.443 * * * \\
(-10.984)\end{array}$ & $\begin{array}{l}-0.355^{* * *} \\
(-10.521)\end{array}$ \\
\hline Market Volatility & $\begin{array}{l}-0.113^{* * *} \\
(-9.049)\end{array}$ & $\begin{array}{l}1.244 * * * \\
(3.575)\end{array}$ & $\begin{array}{l}4.264 * * * \\
(10.564)\end{array}$ & $\begin{array}{l}3.163 * * * \\
(7.067)\end{array}$ & $\begin{array}{l}2.569 * * * \\
(6.931)\end{array}$ & $\begin{array}{l}1.607^{* * *} \\
(4.802)\end{array}$ & $\begin{array}{l}1.302 * * * \\
(3.797)\end{array}$ & $\begin{array}{l}2.951 * * * \\
(7.601)\end{array}$ & $\begin{array}{l}0.356 \\
(1.128)\end{array}$ \\
\hline Macro Proxy & $\begin{array}{l}1.187^{* * *} \\
(3.415) \\
\end{array}$ & $\begin{array}{l}-0.036 * * * \\
(-10.264) \\
\end{array}$ & $\begin{array}{l}-0.033^{* * *} \\
(-16.031) \\
\end{array}$ & $\begin{array}{l}-0.113^{* * *} \\
(-11.739) \\
\end{array}$ & $\begin{array}{l}-0.081 * * * \\
(-13.753) \\
\end{array}$ & $\begin{array}{l}-0.909 * * * \\
(-16.036) \\
\end{array}$ & $\begin{array}{l}-0.366 * * * \\
(-13.517) \\
\end{array}$ & $\begin{array}{l}-2.199 * * * \\
(-13.369) \\
\end{array}$ & $\begin{array}{l}-0.439 * * * \\
(-13.638) \\
\end{array}$ \\
\hline \multicolumn{10}{|c|}{ Panel B: Investors' Risk Aversion } \\
\hline Risk Aversion & $\begin{array}{l}-0.071 * * * \\
(-5.793)\end{array}$ & $\begin{array}{l}-0.033^{* * *} \\
(-2.707)\end{array}$ & $\begin{array}{l}-0.016 \\
(-1.446)\end{array}$ & $\begin{array}{l}-0.022 * \\
(-1.682)\end{array}$ & $\begin{array}{l}-0.023^{*} \\
(-1.839)\end{array}$ & $\begin{array}{l}0.100 * * * \\
(7.488)\end{array}$ & $\begin{array}{l}0.119 * * * \\
(8.336)\end{array}$ & $\begin{array}{l}0.001 \\
(0.043)\end{array}$ & $\begin{array}{l}0.149 * * * \\
(10.326)\end{array}$ \\
\hline Macro Proxy & $\begin{array}{l}-0.037^{* * *} \\
(-3.184) \\
\end{array}$ & $\begin{array}{l}-0.023 * * * \\
(-6.088) \\
\end{array}$ & $\begin{array}{l}-0.020 * * * \\
(-11.590) \\
\end{array}$ & $\begin{array}{l}-0.053 * * * \\
(-6.461) \\
\end{array}$ & $\begin{array}{l}-0.050 * * * \\
(-8.459) \\
\end{array}$ & $\begin{array}{l}-1.176 * * * \\
(-16.968) \\
\end{array}$ & $\begin{array}{l}-0.550 * * * \\
(-16.000) \\
\end{array}$ & $\begin{array}{l}-1.673 * * * \\
(-11.388) \\
\end{array}$ & $\begin{array}{l}-0.749 * * * \\
(-17.024) \\
\end{array}$ \\
\hline \multicolumn{10}{|c|}{ Panel C: Competition form Index Funds } \\
\hline Market Share of index funds & $\begin{array}{l}-0.059 * * * \\
(-5.464)\end{array}$ & $\begin{array}{l}-2.371 * * * \\
(-13.257)\end{array}$ & $\begin{array}{l}-2.126 * * * \\
(-11.487)\end{array}$ & $\begin{array}{l}-2.333^{* * *} \\
(-13.070)\end{array}$ & $\begin{array}{l}-2.287^{* * *} \\
(-12.901)\end{array}$ & $\begin{array}{l}-1.760 * * * \\
(-9.515)\end{array}$ & $\begin{array}{l}-1.950 * * * \\
(-10.432)\end{array}$ & $\begin{array}{l}-2.044^{* * *} \\
(-10.875)\end{array}$ & $\begin{array}{l}-1.871 * * * \\
(-9.976)\end{array}$ \\
\hline Macro Proxy & $\begin{array}{l}-2.377^{* * *} \\
(-13.295)\end{array}$ & $\begin{array}{l}-0.020 * * * \\
(-6.868)\end{array}$ & $\begin{array}{l}-0.008 * * * \\
(-5.260)\end{array}$ & $\begin{array}{l}-0.036 * * * \\
(-5.832)\end{array}$ & $\begin{array}{l}-0.034^{* * *} \\
(-7.588)\end{array}$ & $\begin{array}{l}-0.553 * * * \\
(-10.176)\end{array}$ & $\begin{array}{l}-0.212 * * * \\
(-8.124)\end{array}$ & $\begin{array}{l}-0.757^{* * *} \\
(-5.555)\end{array}$ & $\begin{array}{l}-0.294 * * * \\
(-8.707)\end{array}$ \\
\hline
\end{tabular}


Table 10

Advertising Budget and Firm Characteristics

The table reports descriptive statistics of the advertising subsample. The first three columns show sample coverage, columns 4 and 5 show advertising volumes by budget (millions of US\$) and quantities (in units). The last four columns report the breakdown of advertising budget by media category.

\begin{tabular}{|c|c|c|c|c|c|c|c|c|c|}
\hline \multirow[b]{2}{*}{ Year } & \multicolumn{3}{|c|}{ Sample Coverage } & \multicolumn{2}{|c|}{ Advertising Volume } & \multicolumn{4}{|c|}{ Advertising Budget per Medium } \\
\hline & $\begin{array}{c}\text { N. of Inv. } \\
\text { Companies }\end{array}$ & $\begin{array}{l}\text { N. of } \\
\text { Funds }\end{array}$ & AUM & $\begin{array}{c}\text { Budget } \\
\text { (m\$) }\end{array}$ & $\begin{array}{l}\text { N. of units } \\
(000)\end{array}$ & $\begin{array}{c}\text { Radio \& } \\
\text { TV }\end{array}$ & Press & Internet & Other \\
\hline 2001 & $35.0 \%$ & $65.4 \%$ & $87.1 \%$ & 345.4 & 60.7 & $47.0 \%$ & $52.8 \%$ & $0.1 \%$ & $0.1 \%$ \\
\hline 2002 & $37.6 \%$ & $68.7 \%$ & $87.0 \%$ & 200.3 & 49.5 & $45.3 \%$ & $54.3 \%$ & $0.1 \%$ & $0.3 \%$ \\
\hline 2003 & $38.6 \%$ & $70.8 \%$ & $87.4 \%$ & 198.4 & 32.0 & $45.1 \%$ & $54.7 \%$ & $0.0 \%$ & $0.2 \%$ \\
\hline 2004 & $37.7 \%$ & $72.0 \%$ & $86.9 \%$ & 284.6 & 39.0 & $57.7 \%$ & $42.2 \%$ & $0.1 \%$ & $0.1 \%$ \\
\hline 2005 & $39.6 \%$ & $74.0 \%$ & $87.8 \%$ & 307.3 & 43.7 & $52.6 \%$ & $47.0 \%$ & $0.2 \%$ & $0.2 \%$ \\
\hline 2006 & $39.1 \%$ & $74.4 \%$ & $87.5 \%$ & 301.0 & 58.4 & $43.0 \%$ & $50.2 \%$ & $1.9 \%$ & $5.0 \%$ \\
\hline 2007 & $40.0 \%$ & $75.7 \%$ & $87.7 \%$ & 245.1 & 70.7 & $36.1 \%$ & $55.6 \%$ & $1.8 \%$ & $6.4 \%$ \\
\hline 2008 & $39.5 \%$ & $76.6 \%$ & $88.9 \%$ & 229.7 & 67.1 & $32.1 \%$ & $57.8 \%$ & $2.3 \%$ & $7.8 \%$ \\
\hline 2009 & $41.2 \%$ & $79.8 \%$ & $90.6 \%$ & 125.2 & 64.2 & $31.7 \%$ & $47.6 \%$ & $11.5 \%$ & $9.3 \%$ \\
\hline 2010 & $39.3 \%$ & $80.0 \%$ & $91.4 \%$ & 123.5 & 58.6 & $20.2 \%$ & $59.0 \%$ & $8.3 \%$ & $12.5 \%$ \\
\hline 2001-2010 & $38.5 \%$ & $73.4 \%$ & $88.2 \%$ & 2360.6 & 543.8 & $43.4 \%$ & $51.5 \%$ & $1.8 \%$ & $3.3 \%$ \\
\hline
\end{tabular}


Table 11

Advertising Budget and Firm Characteristics

The table reports mean values (and standard errors in parenthesis) for a number of characteristics of investment companies separately for the subsamples low and high advertisers defined as companies with total advertising budget (Panel A) or total normalized advertising budget (Panel B) in the 2001-2010 period below or above the sample median. Normalized advertising budget is calculated each year by dividing the advertising budget by the asset under management of the company. The third column reports the differences (with standard errors) and significance levels. $* * *, * *$ and $*$ represent significance at the $1 \%, 5 \%$ and $10 \%$ respectively.

\begin{tabular}{|c|c|c|c|}
\hline \multicolumn{4}{|c|}{ Panel A: Total Advertising Budget } \\
\hline & $\begin{array}{c}\text { Low } \\
\text { Advertisers }\end{array}$ & $\begin{array}{c}\text { High } \\
\text { Advertiser }\end{array}$ & Difference \\
\hline Inv. Company Size & $\begin{array}{c}10547.7 \\
(1281.563)\end{array}$ & $\begin{array}{c}32892.2 \\
(1760.077)\end{array}$ & $\begin{array}{c}22344.5^{* * *} \\
(2177.217)\end{array}$ \\
\hline Fund Size & $\begin{array}{c}586.6 \\
(19.741)\end{array}$ & $\begin{array}{c}943.6 \\
(30.101)\end{array}$ & $\begin{array}{c}356.9 * * * \\
(35.997)\end{array}$ \\
\hline Fund Age & $\begin{array}{c}13.8811 \\
(0.116)\end{array}$ & $\begin{array}{c}15.4338 \\
(0.115)\end{array}$ & $\begin{array}{l}1.6 * * * \\
(0.163)\end{array}$ \\
\hline Expense Ratio & $\begin{array}{l}-0.2289 \\
(0.015)\end{array}$ & $\begin{array}{l}-0.4255 \\
(0.015)\end{array}$ & $\begin{array}{c}-0.1966^{* * *} \\
(0.021)\end{array}$ \\
\hline Expense Ratio (net of $12 b-1$ fees) & $\begin{array}{l}0.3057 \\
(0.021)\end{array}$ & $\begin{array}{l}-0.2897 \\
(0.020)\end{array}$ & $\begin{array}{c}-0.5954 * * * \\
(0.029)\end{array}$ \\
\hline Normalized Performance & $\begin{array}{l}0.1137 \\
(0.023)\end{array}$ & $\begin{array}{l}-0.0581 \\
(0.014)\end{array}$ & $\begin{array}{c}-0.1718^{* * *} \\
(0.027)\end{array}$ \\
\hline Normalized Standard Deviation & $\begin{array}{l}0.1185 \\
(0.022)\end{array}$ & $\begin{array}{l}-0.0466 \\
(0.013)\end{array}$ & $\begin{array}{c}-0.1651^{* * *} \\
(0.025)\end{array}$ \\
\hline \multicolumn{4}{|c|}{ Panel B: Normalized Total Advertising Budget } \\
\hline & $\begin{array}{c}\text { Low } \\
\text { Advertisers }\end{array}$ & $\begin{array}{c}\text { High } \\
\text { Advertiser } \\
\end{array}$ & Difference \\
\hline Inv. Company Size & $\begin{array}{c}23557.2 \\
(1821.942)\end{array}$ & $\begin{array}{c}19737.6 \\
(1261.921)\end{array}$ & $\begin{array}{c}-3819.6 * \\
(2216.284)\end{array}$ \\
\hline Fund Size & $\begin{array}{c}842.2 \\
(29.484)\end{array}$ & $\begin{array}{c}688.1 \\
(21.462)\end{array}$ & $\begin{array}{c}-154.2^{* * *} \\
(36.468)\end{array}$ \\
\hline Fund Age & $\begin{array}{c}14.8311 \\
(0.112)\end{array}$ & $\begin{array}{c}14.4761 \\
(0.120)\end{array}$ & $\begin{array}{l}-0.4 * * \\
(0.164)\end{array}$ \\
\hline Expense Ratio & $\begin{array}{l}-0.3333 \\
(0.014)\end{array}$ & $\begin{array}{l}-0.3192 \\
(0.016)\end{array}$ & $\begin{array}{l}0.0141 \\
(0.021)\end{array}$ \\
\hline Expense Ratio (net of $12 b-1$ fees) & $\begin{array}{c}-0.0214 \\
(0.021)\end{array}$ & $\begin{array}{l}0.0422 \\
(0.022)\end{array}$ & $\begin{array}{c}0.0636 * * \\
(0.030)\end{array}$ \\
\hline Normalized Performance & $\begin{array}{l}0.0905 \\
(0.019)\end{array}$ & $\begin{array}{l}-0.0299 \\
(0.020)\end{array}$ & $\begin{array}{c}-0.1204 * * * \\
(0.027)\end{array}$ \\
\hline Normalized Standard Deviation & $\begin{array}{c}-0.0336 \\
(0.018)\end{array}$ & $\begin{array}{l}0.1036 \\
(0.018)\end{array}$ & $\begin{array}{c}0.1372 * * * \\
(0.026)\end{array}$ \\
\hline
\end{tabular}


Table 12

Investment Flows and Advertising

The table reports the relationship between the quarterly net investment flow and the set of explanatory variables described in Table 1 and a measure of advertising activity. In Models 1 to 4 advertising is proxied by the (natural $\log$ of) total advertising budget of the investment company. In Model 5 to 8 advertising is proxied by the investment company share of the industry advertising budget for the quarter. I consider on a sample of mutual fund shares from 1991 to 2011. The relationship is estimated with a panel regression with fund fixed effects. T-statistics in parentheses. $* * *, * *$ and $*$ represent significance at the $1 \%, 5 \%$ and $10 \%$ respectively.

\begin{tabular}{|c|c|c|c|c|c|c|c|c|}
\hline & (1) & (2) & (3) & (4) & (5) & (6) & (7) & (8) \\
\hline & \multicolumn{4}{|c|}{ Log (Adv. Budget) } & \multicolumn{4}{|c|}{ Adv. Market Share } \\
\hline \multirow[t]{2}{*}{ Constant } & $3.120 * * *$ & $3.130 * * *$ & $3.123 * * *$ & $3.134 * * *$ & $3.162 * * *$ & $3.163^{* * *}$ & $3.173^{* * *}$ & $3.174 * * *$ \\
\hline & (11.010) & $(11.061)$ & (11.029) & $(11.082)$ & $(11.160)$ & (11.178) & (11.187) & (11.206) \\
\hline \multirow[t]{2}{*}{ Perf } & $0.140 * * *$ & $0.159 * * *$ & $0.140 * * *$ & $0.159 * * *$ & $0.140 * * *$ & $0.156^{* * *}$ & $0.140 * * *$ & $0.156^{* * *}$ \\
\hline & (12.299) & $(11.396)$ & $(12.305)$ & $(11.410)$ & $(12.261)$ & $(12.552)$ & $(12.270)$ & $(12.560)$ \\
\hline \multirow[t]{2}{*}{ Mid } & $0.080 * * *$ & $0.080 * * *$ & $0.080 * * *$ & $0.080 * * *$ & $0.080 * * *$ & $0.078 * * *$ & $0.080 * * *$ & $0.077 * * *$ \\
\hline & $(6.576)$ & $(6.492)$ & $(6.584)$ & $(6.501)$ & (6.589) & $(6.303)$ & $(6.587)$ & $(6.300)$ \\
\hline \multirow[t]{2}{*}{ High } & $0.180 * * *$ & $0.182 * * *$ & $0.180 * * *$ & $0.182 * * *$ & $0.181 * * *$ & $0.179 * * *$ & $0.181 * * *$ & $0.179 * * *$ \\
\hline & $(8.121)$ & $(8.041)$ & $(8.125)$ & $(8.045)$ & $(8.148)$ & $(7.901)$ & $(8.145)$ & (7.898) \\
\hline \multirow[t]{2}{*}{ Exp } & $-0.105 * *$ & $-0.101 * *$ & $-0.114 * * *$ & $-0.112 * * *$ & $-0.104 * *$ & $-0.103 * *$ & $-0.092 * *$ & $-0.091 * *$ \\
\hline & $(-2.494)$ & $(-2.428)$ & $(-2.649)$ & $(-2.605)$ & $(-2.492)$ & $(-2.463)$ & $(-2.187)$ & $(-2.155)$ \\
\hline \multirow[t]{2}{*}{ Size } & $-0.171 * * *$ & $-0.171 * * *$ & $-0.171 * * *$ & $-0.171 * * *$ & $-0.170 * * *$ & $-0.169 * * *$ & $-0.170 * * *$ & $-0.169 * * *$ \\
\hline & $(-11.848)$ & $(-11.872)$ & $(-11.860)$ & $(-11.885)$ & $(-11.836)$ & $(-11.779)$ & $(-11.853)$ & $(-11.796)$ \\
\hline \multirow[t]{2}{*}{ Age } & $-0.669 * * *$ & $-0.670 * * *$ & $-0.669 * * *$ & $-0.671 * * *$ & $-0.675 * * *$ & $-0.674^{* * *}$ & $-0.676 * * *$ & $-0.676 * * *$ \\
\hline & $(-16.675)$ & $(-16.732)$ & $(-16.692)$ & $(-16.751)$ & $(-16.893)$ & $(-16.905)$ & $(-16.917)$ & $(-16.930)$ \\
\hline \multirow[t]{2}{*}{ Loads } & $-0.224 * * *$ & $-0.223 * * *$ & $-0.224 * * *$ & $-0.223 * * *$ & $-0.224 * * *$ & $-0.224 * * *$ & $-0.223 * * *$ & $-0.223 * * *$ \\
\hline & $(-4.359)$ & $(-4.340)$ & $(-4.365)$ & $(-4.347)$ & $(-4.364)$ & $(-4.369)$ & $(-4.346)$ & $(-4.351)$ \\
\hline \multirow[t]{2}{*}{ Institutional } & -0.125 & -0.126 & -0.125 & -0.127 & -0.126 & -0.127 & -0.126 & -0.126 \\
\hline & $(-0.840)$ & $(-0.853)$ & $(-0.844)$ & $(-0.857)$ & $(-0.850)$ & $(-0.856)$ & $(-0.848)$ & $(-0.854)$ \\
\hline \multirow[t]{2}{*}{ St. Dev. } & 0.002 & 0.001 & 0.002 & 0.001 & 0.002 & 0.001 & 0.002 & 0.001 \\
\hline & $(0.188)$ & $(0.100)$ & $(0.174)$ & $(0.084)$ & $(0.171)$ & $(0.114)$ & $(0.208)$ & (0.151) \\
\hline \multirow[t]{2}{*}{ IC Size } & $0.108 * * *$ & $0.108 * * *$ & $0.108 * * *$ & $0.108 * * *$ & $0.108 * * *$ & $0.107 * * *$ & $0.107 * * *$ & $0.106^{* * *}$ \\
\hline & $(4.909)$ & $(4.916)$ & $(4.915)$ & $(4.923)$ & $(4.907)$ & $(4.882)$ & $(4.881)$ & $(4.855)$ \\
\hline \multirow[t]{2}{*}{ Advertising } & $0.006^{* *}$ & $0.006 * *$ & $0.006^{* *}$ & $0.006 * *$ & $0.334 * *$ & $0.387 * * *$ & 0.210 & $0.262^{*}$ \\
\hline & $(2.416)$ & $(2.380)$ & $(2.286)$ & $(2.241)$ & $(2.389)$ & $(2.746)$ & $(1.523)$ & $(1.894)$ \\
\hline \multirow[t]{2}{*}{ Advertising $x$ Perf } & & $-0.006 * * *$ & & $-0.006 * * *$ & & $-0.597 * * *$ & & $-0.599 * * *$ \\
\hline & & $(-3.247)$ & & $(-3.273)$ & & $(-5.171)$ & & $(-5.198)$ \\
\hline \multirow[t]{2}{*}{ Advertising $x$ Exp } & & & 0.003 & 0.003 & & & $-0.448 * * *$ & $-0.454 * * *$ \\
\hline & & & $(1.117)$ & $(1.218)$ & & & $(-3.260)$ & $(-3.253)$ \\
\hline$N$ & 71012 & 71012 & 71012 & 71012 & 71012 & 71012 & 71012 & 71012 \\
\hline adj. R-sq & 0.092 & 0.093 & 0.092 & 0.093 & 0.092 & 0.093 & 0.092 & 0.093 \\
\hline
\end{tabular}


Table 13

\section{Advertising in Tough Times}

The table reports panel estimation with fund fixed effect of the interaction coefficients ( $\lambda$ coefficients in Equation 3 ) between the nine macroeconomic proxy variables and the explanatory variables described in Table 1 as well as a measure of advertising activity proxied by the (natural log of) investment company advertising budget (Panel A) or the company share of the industry advertising budget (Panel B). T-statistics in parentheses. ***,** and * represent significance at the $1 \%, 5 \%$ and $10 \%$ respectively.

\begin{tabular}{|c|c|c|c|c|c|c|c|c|c|}
\hline \multicolumn{10}{|c|}{ Panel A: Log (Advertising Budget) } \\
\hline & (1) & (2) & (3) & (4) & (5) & (6) & (7) & (8) & (9) \\
\hline & $\begin{array}{c}\text { NBER } \\
\text { Recession }\end{array}$ & $\begin{array}{l}\Delta \text { Industrial } \\
\text { Production }\end{array}$ & $\begin{array}{l}\text { Capacity } \\
\text { Utilization }\end{array}$ & $\begin{array}{c}\Delta \\
\text { Coincident } \\
\text { Index }\end{array}$ & $\begin{array}{l}\text { Leading } \\
\text { Index }\end{array}$ & $\begin{array}{l}\text { Consumer } \\
\text { Sentiment }\end{array}$ & $\begin{array}{l}\text { Consumer } \\
\text { Confidence }\end{array}$ & $\begin{array}{l}\text { NFIB Small } \\
\text { Bus. } \\
\text { Optimism }\end{array}$ & $\begin{array}{c}\text { ABC WP } \\
\text { Cons. } \\
\text { Comfort }\end{array}$ \\
\hline Constant & $\begin{array}{c}-0.054 \\
(-0.429)\end{array}$ & $\begin{array}{c}-0.087^{* *} \\
(-2.235)\end{array}$ & $\begin{array}{c}-0.007 \\
(-0.326)\end{array}$ & $\begin{array}{c}-0.100 \\
(-1.140)\end{array}$ & $\begin{array}{l}-0.120^{*} \\
(-1.884)\end{array}$ & $\begin{array}{c}1.867^{* *} \\
(2.466)\end{array}$ & $\begin{array}{c}0.691^{* *} \\
(2.089)\end{array}$ & $\begin{array}{c}4.395 * * * \\
(2.645)\end{array}$ & $\begin{array}{c}1.476^{* * *} \\
(3.251)\end{array}$ \\
\hline Perf & $\begin{array}{c}-0.030 \\
(-1.462)\end{array}$ & $\begin{array}{c}-0.021 * * * \\
(-3.747)\end{array}$ & $\begin{array}{c}-0.004 \\
(-1.638)\end{array}$ & $\begin{array}{c}-0.013 \\
(-1.147)\end{array}$ & $\begin{array}{c}-0.021 * * \\
(-2.560)\end{array}$ & $\begin{array}{c}-0.360 * * * \\
(-4.374)\end{array}$ & $\begin{array}{c}-0.154^{* * *} \\
(-3.737)\end{array}$ & $\begin{array}{c}-0.443^{* * *} \\
(-2.661)\end{array}$ & $\begin{array}{c}-0.184 * * * \\
(-3.244)\end{array}$ \\
\hline Mid & $\begin{array}{c}0.042 \\
(1.532)\end{array}$ & $\begin{array}{c}0.019 * * * \\
(2.607)\end{array}$ & $\begin{array}{c}-0.008^{* *} \\
(-2.330)\end{array}$ & $\begin{array}{c}0.007 \\
(0.491)\end{array}$ & $\begin{array}{l}0.018^{*} \\
(1.768)\end{array}$ & $\begin{array}{c}0.199 * * \\
(2.013)\end{array}$ & $\begin{array}{c}-0.014 \\
(-0.295)\end{array}$ & $\begin{array}{c}-0.005 \\
(-0.028)\end{array}$ & $\begin{array}{c}0.002 \\
(0.034)\end{array}$ \\
\hline High & $\begin{array}{l}0.084^{*} \\
(1.820)\end{array}$ & $\begin{array}{c}0.032^{* * *} \\
(2.588)\end{array}$ & $\begin{array}{c}-0.015^{* * *} \\
(-2.672)\end{array}$ & $\begin{array}{c}0.005 \\
(0.201)\end{array}$ & $\begin{array}{c}0.028 \\
(1.557)\end{array}$ & $\begin{array}{c}0.282 \\
(1.584)\end{array}$ & $\begin{array}{l}-0.037 \\
(-0.428)\end{array}$ & $\begin{array}{c}-0.016 \\
(-0.046)\end{array}$ & $\begin{array}{c}0.018 \\
(0.154)\end{array}$ \\
\hline $\operatorname{Exp}$ & $\begin{array}{c}-0.045^{* * *} \\
(-3.466)\end{array}$ & $\begin{array}{c}-0.010^{* * *} \\
(-3.013)\end{array}$ & $\begin{array}{c}-0.001 \\
(-0.429)\end{array}$ & $\begin{array}{c}-0.016^{* *} \\
(-2.068)\end{array}$ & $\begin{array}{c}-0.021^{* * *} \\
(-3.831)\end{array}$ & $\begin{array}{r}-0.819 * * * \\
(-11.109)\end{array}$ & $\begin{array}{c}-0.325^{* * *} \\
(-9.674)\end{array}$ & $\begin{array}{c}-1.421 * * * \\
(-9.230)\end{array}$ & $\begin{array}{r}-0.581 * * * \\
(-11.900)\end{array}$ \\
\hline Size & $\begin{array}{c}-0.009 \\
(-1.055)\end{array}$ & $\begin{array}{l}-0.004^{*} \\
(-1.717)\end{array}$ & $\begin{array}{c}-0.001 \\
(-0.661)\end{array}$ & $\begin{array}{c}-0.005 \\
(-0.943)\end{array}$ & $\begin{array}{l}-0.007^{*} \\
(-1.956)\end{array}$ & $\begin{array}{c}-0.302 * * * \\
(-7.121)\end{array}$ & $\begin{array}{c}-0.129 * * * \\
(-6.553)\end{array}$ & $\begin{array}{c}-0.475^{* * *} \\
(-5.426)\end{array}$ & $\begin{array}{c}-0.225 * * * \\
(-8.130)\end{array}$ \\
\hline Age & $\begin{array}{c}0.019 \\
(0.858)\end{array}$ & $\begin{array}{c}0.011 \\
(1.538)\end{array}$ & $\begin{array}{c}0.009 * * \\
(2.296)\end{array}$ & $\begin{array}{c}0.034^{* *} \\
(2.139)\end{array}$ & $\begin{array}{c}0.032 * * * \\
(2.723)\end{array}$ & $\begin{array}{c}0.391 * * * \\
(2.900)\end{array}$ & $\begin{array}{c}0.182 * * * \\
(3.034)\end{array}$ & $\begin{array}{c}0.726^{* *} \\
(2.411)\end{array}$ & $\begin{array}{c}0.261^{* * *} \\
(3.232)\end{array}$ \\
\hline No Load & $\begin{array}{c}-0.102 * * * \\
(-3.461)\end{array}$ & $\begin{array}{c}-0.021 * * * \\
(-2.741)\end{array}$ & $\begin{array}{c}-0.007 \\
(-1.486)\end{array}$ & $\begin{array}{c}-0.044 * * \\
(-2.486)\end{array}$ & $\begin{array}{c}-0.031 * * \\
(-2.451)\end{array}$ & $\begin{array}{l}-0.294^{*} \\
(-1.706)\end{array}$ & $\begin{array}{c}-0.066 \\
(-0.835)\end{array}$ & $\begin{array}{c}-0.728^{* *} \\
(-2.027)\end{array}$ & $\begin{array}{c}-0.093 \\
(-0.828)\end{array}$ \\
\hline Institutional & $\begin{array}{c}-0.006 \\
(-0.175)\end{array}$ & $\begin{array}{c}-0.001 \\
(-0.067)\end{array}$ & $\begin{array}{c}0.005 \\
(0.905)\end{array}$ & $\begin{array}{c}0.011 \\
(0.552)\end{array}$ & $\begin{array}{c}0.009 \\
(0.595)\end{array}$ & $\begin{array}{c}-0.298 \\
(-1.524)\end{array}$ & $\begin{array}{c}-0.130 \\
(-1.448)\end{array}$ & $\begin{array}{c}-0.345 \\
(-0.846)\end{array}$ & $\begin{array}{l}-0.241^{*} \\
(-1.882)\end{array}$ \\
\hline St. Dev. & $\begin{array}{c}0.124 * * * \\
(11.219)\end{array}$ & $\begin{array}{c}0.031 * * * \\
(10.087)\end{array}$ & $\begin{array}{c}0.009 * * * \\
(5.220)\end{array}$ & $\begin{array}{c}0.079 * * * \\
(10.903)\end{array}$ & $\begin{array}{c}0.050 * * * \\
(10.250)\end{array}$ & $\begin{array}{c}0.394 * * * \\
(7.351)\end{array}$ & $\begin{array}{c}0.165 * * * \\
(6.191)\end{array}$ & $\begin{array}{c}0.814^{* * *} \\
(6.916)\end{array}$ & $\begin{array}{c}0.178^{* * *} \\
(4.901)\end{array}$ \\
\hline IC Size & $\begin{array}{c}-0.003 \\
(-0.439)\end{array}$ & $\begin{array}{c}0.004^{* *} \\
(2.130)\end{array}$ & $\begin{array}{c}-0.004 * * * \\
(-3.802)\end{array}$ & $\begin{array}{l}-0.007^{*} \\
(-1.865)\end{array}$ & $\begin{array}{c}-0.002 \\
(-0.829)\end{array}$ & $\begin{array}{c}-0.258^{* * *} \\
(-6.507)\end{array}$ & $\begin{array}{c}-0.107^{* * *} \\
(-6.241)\end{array}$ & $\begin{array}{c}-0.603^{* * *} \\
(-7.379)\end{array}$ & $\begin{array}{c}-0.182^{* * *} \\
(-7.288)\end{array}$ \\
\hline Advertising & $\begin{array}{c}-0.001 \\
(-0.349) \\
\end{array}$ & $\begin{array}{c}-0.002 * * \\
(-2.113) \\
\end{array}$ & $\begin{array}{c}0.002^{* * *} \\
(4.141) \\
\end{array}$ & $\begin{array}{c}0.003 \\
(1.464) \\
\end{array}$ & $\begin{array}{c}0.000 \\
(0.333) \\
\end{array}$ & $\begin{array}{c}0.099 * * * \\
(6.095) \\
\end{array}$ & $\begin{array}{c}0.052^{* * *} \\
(6.775) \\
\end{array}$ & $\begin{array}{c}0.226 * * * \\
(6.586) \\
\end{array}$ & $\begin{array}{c}0.083^{* * *} \\
(7.791) \\
\end{array}$ \\
\hline $\mathrm{N}$ & 71012 & 71012 & 71012 & 71012 & 71012 & 71012 & 71012 & 71012 & 71012 \\
\hline adj. R-sq & 0.096 & 0.096 & 0.097 & 0.099 & 0.097 & 0.106 & 0.105 & 0.105 & 0.108 \\
\hline
\end{tabular}


(Table description in previous Page)

\begin{tabular}{|c|c|c|c|c|c|c|c|c|c|}
\hline \multicolumn{10}{|c|}{ Panel B: Advertising Market Share } \\
\hline & (1) & (2) & (3) & (4) & (5) & (6) & (7) & (8) & (9) \\
\hline & $\begin{array}{c}\text { NBER } \\
\text { Recession }\end{array}$ & $\begin{array}{l}\Delta \text { Industrial } \\
\text { Production }\end{array}$ & $\begin{array}{l}\text { Capacity } \\
\text { Utilization }\end{array}$ & $\underset{\substack{\Delta \\
\text { Coincident } \\
\text { Index }}}{ }$ & $\begin{array}{l}\text { Leading } \\
\text { Index }\end{array}$ & $\begin{array}{l}\text { Consumer } \\
\text { Sentiment }\end{array}$ & $\begin{array}{l}\text { Consumer } \\
\text { Confidence }\end{array}$ & $\begin{array}{l}\text { NFIB Small } \\
\text { Bus. } \\
\text { Optimism }\end{array}$ & $\begin{array}{c}\text { ABC WP } \\
\text { Cons. } \\
\text { Comfort }\end{array}$ \\
\hline \multirow[t]{2}{*}{ Constant } & -0.036 & $-0.081^{* *}$ & -0.002 & -0.083 & $-0.107 *$ & $2.029 * * *$ & $0.797^{* *}$ & $4.754^{* * *}$ & $1.777^{* * *}$ \\
\hline & $(-0.288)$ & $(-2.088)$ & $(-0.091)$ & $(-0.945)$ & $(-1.686)$ & $(2.636)$ & $(2.391)$ & $(2.827)$ & $(3.875)$ \\
\hline \multirow[t]{2}{*}{ Perf } & -0.030 & $-0.021 * * *$ & -0.004 & -0.013 & $-0.021 * *$ & $-0.368 * * *$ & $-0.154 * * *$ & $-0.455^{* * *}$ & $-0.185^{* * *}$ \\
\hline & $(-1.442)$ & $(-3.725)$ & $(-1.584)$ & $(-1.134)$ & $(-2.542)$ & $(-4.483)$ & $(-3.738)$ & $(-2.729)$ & $(-3.256)$ \\
\hline \multirow[t]{2}{*}{ Mid } & 0.042 & $0.019 * * *$ & $-0.008 * *$ & 0.007 & $0.018^{*}$ & $0.199 * *$ & -0.017 & -0.001 & -0.005 \\
\hline & $(1.527)$ & $(2.653)$ & $(-2.392)$ & $(0.483)$ & (1.753) & $(2.003)$ & $(-0.346)$ & $(-0.004)$ & $(-0.080)$ \\
\hline \multirow[t]{2}{*}{ High } & $0.084^{*}$ & $0.032 * *$ & $-0.016 * * *$ & 0.005 & 0.028 & $0.295^{*}$ & -0.038 & 0.002 & 0.021 \\
\hline & (1.820) & $(2.576)$ & $(-2.755)$ & $(0.190)$ & (1.556) & $(1.658)$ & $(-0.445)$ & (0.005) & (0.174) \\
\hline \multirow[t]{2}{*}{ Exp } & $-0.045^{* * *}$ & $-0.009 * * *$ & -0.002 & $-0.017^{* *}$ & $-0.022 * * *$ & $-0.854 * * *$ & $-0.343^{* * *}$ & $-1.506 * * *$ & $-0.611^{* * *}$ \\
\hline & $(-3.510)$ & $(-2.756)$ & $(-0.888)$ & $(-2.237)$ & $(-3.905)$ & $(-11.503)$ & $(-10.168)$ & $(-9.696)$ & $(-12.396)$ \\
\hline \multirow[t]{2}{*}{ Size } & -0.008 & $-0.004^{*}$ & -0.001 & -0.004 & $-0.007^{*}$ & $-0.299 * * *$ & $-0.128^{* * *}$ & $-0.467 * * *$ & $-0.222^{* * *}$ \\
\hline & $(-1.032)$ & $(-1.675)$ & $(-0.678)$ & $(-0.887)$ & $(-1.896)$ & $(-6.984)$ & $(-6.464)$ & $(-5.255)$ & $(-7.970)$ \\
\hline \multirow[t]{2}{*}{ Age } & 0.017 & $0.012^{*}$ & $0.007^{*}$ & $0.030 *$ & $0.029 * *$ & $0.304 * *$ & $0.141^{* *}$ & $0.512^{*}$ & $0.174 * *$ \\
\hline & (0.787) & $(1.670)$ & (1.824) & $(1.912)$ & $(2.572)$ & $(2.276)$ & $(2.373)$ & (1.711) & (2.189) \\
\hline \multirow[t]{2}{*}{ No Load } & $-0.100 * * *$ & $-0.020 * * *$ & -0.006 & $-0.043 * *$ & $-0.031^{* *}$ & $-0.298^{*}$ & -0.066 & $-0.731^{* *}$ & -0.089 \\
\hline & $(-3.413)$ & $(-2.688)$ & $(-1.432)$ & $(-2.427)$ & $(-2.406)$ & $(-1.725)$ & $(-0.838)$ & $(-2.022)$ & $(-0.791)$ \\
\hline \multirow[t]{2}{*}{ Institutional } & -0.009 & 0.001 & 0.002 & 0.008 & 0.007 & $-0.395^{* *}$ & $-0.176 * *$ & -0.571 & $-0.325^{* *}$ \\
\hline & $(-0.255)$ & (0.151) & $(0.472)$ & $(0.382)$ & $(0.490)$ & $(-2.037)$ & $(-1.975)$ & $(-1.405)$ & $(-2.549)$ \\
\hline \multirow[t]{2}{*}{ St. Dev. } & $0.124 * * *$ & $0.031 * * *$ & $0.009 * * *$ & $0.079 * * *$ & $0.050 * * *$ & $0.398 * * *$ & $0.166^{* * *}$ & $0.826 * * *$ & $0.181^{* * *}$ \\
\hline & (11.244) & (10.071) & $(5.292)$ & (10.929) & (10.267) & $(7.430)$ & (6.219) & $(7.016)$ & (4.963) \\
\hline \multirow[t]{2}{*}{ IC Size } & -0.004 & 0.002 & $-0.003 * * *$ & $-0.006^{*}$ & -0.003 & $-0.208 * * *$ & $-0.086^{* * *}$ & $-0.482 * * *$ & $-0.149 * * *$ \\
\hline & $(-0.575)$ & (1.305) & $(-2.845)$ & $(-1.705)$ & $(-0.869)$ & $(-5.190)$ & $(-4.928)$ & $(-5.869)$ & $(-5.816)$ \\
\hline \multirow[t]{2}{*}{ Advertising } & -0.105 & -0.028 & $0.070 * * *$ & 0.102 & -0.003 & $3.268^{* * *}$ & $2.065^{* * *}$ & $7.218^{* * *}$ & $3.320 * * *$ \\
\hline & $(-0.504)$ & $(-0.534)$ & $(2.580)$ & $(1.013)$ & $(-0.037)$ & $(3.266)$ & $(4.233)$ & (3.567) & (4.549) \\
\hline $\mathrm{N}$ & 71012 & 71012 & 71012 & 71012 & 71012 & 71012 & 71012 & 71012 & 71012 \\
\hline adj. R-sq & 0.096 & 0.096 & 0.097 & 0.099 & 0.097 & 0.105 & 0.104 & 0.104 & 0.106 \\
\hline
\end{tabular}


Figure 1

Present Economic Situation and Future Expectations
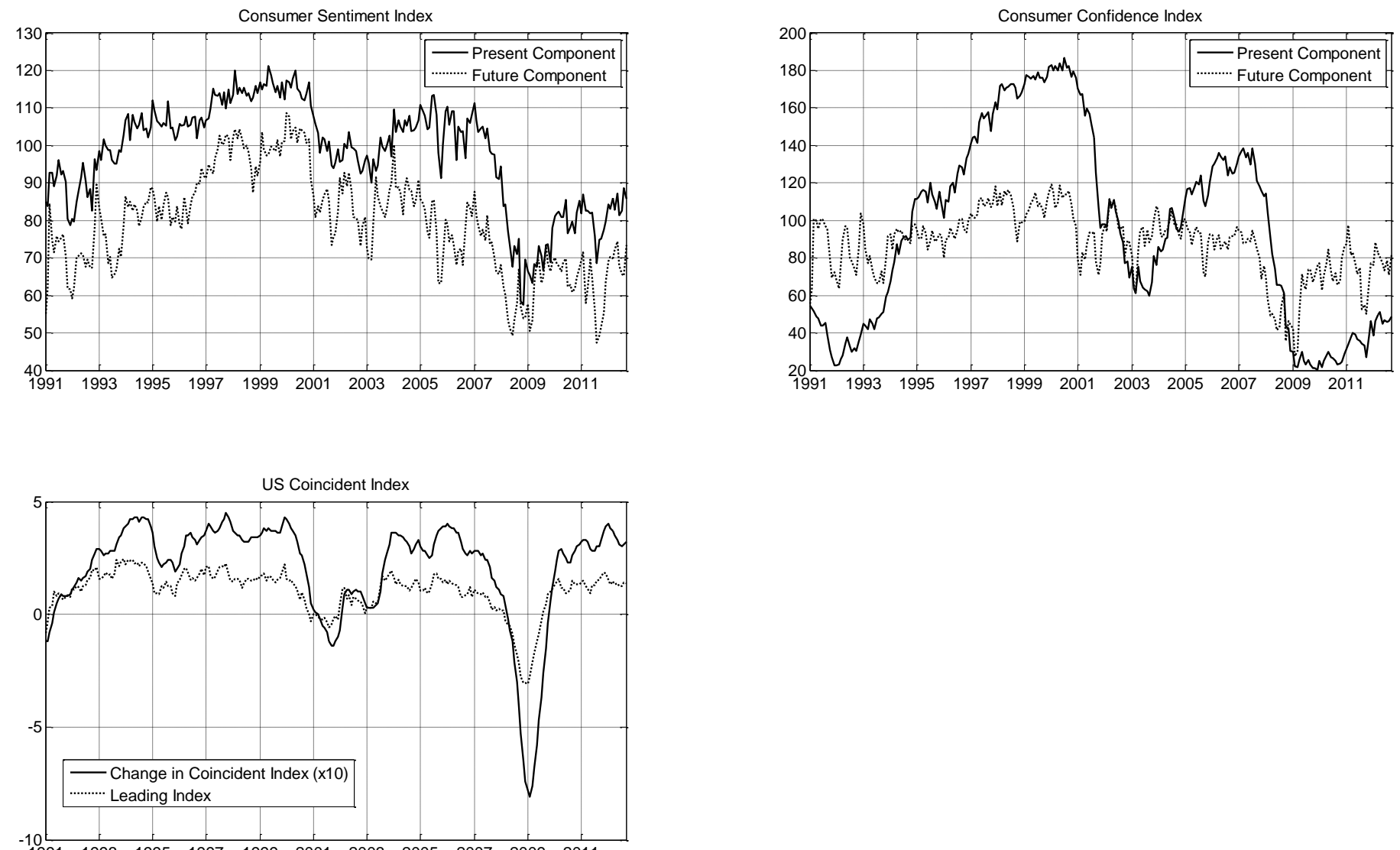
Figure 2

Consumer Confidence Index and time-varying risk aversion

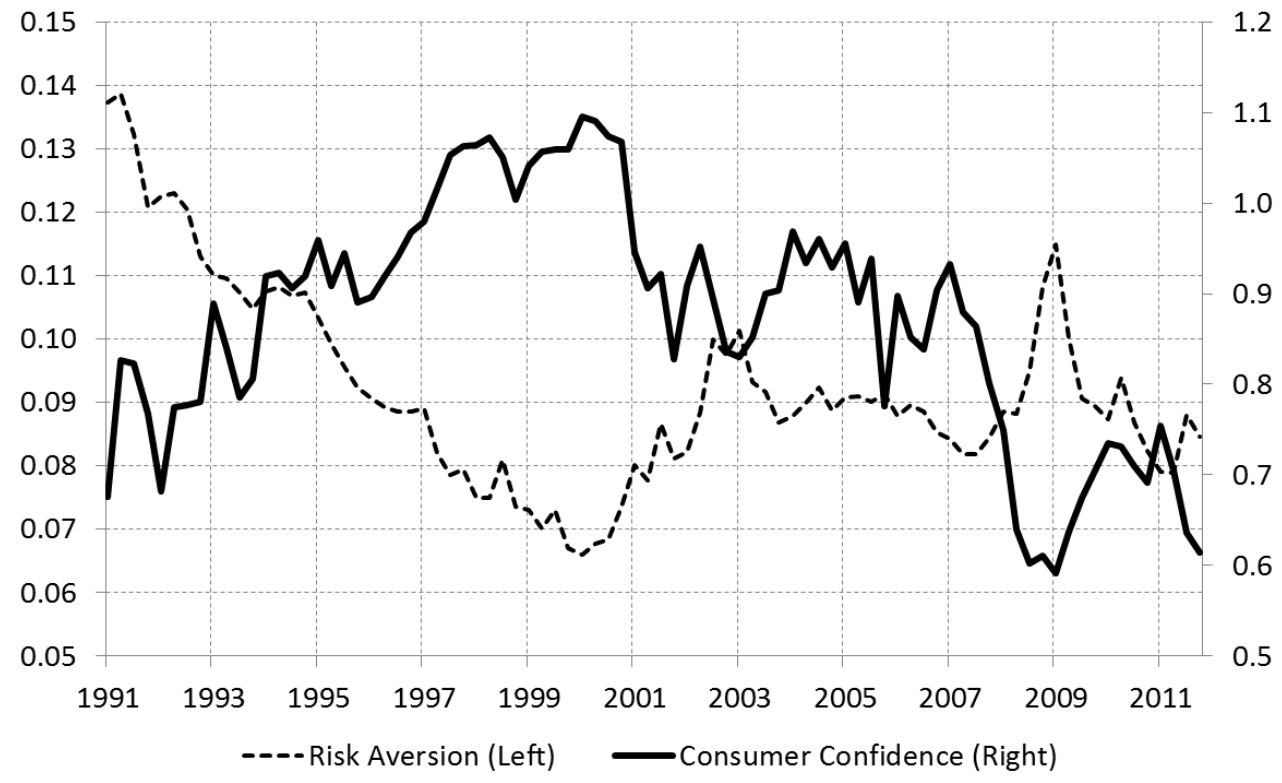

